\title{
Evolution of a Neoproterozoic
} suture in the Iberian Massif, Central Portugal: new U-Pb ages of igneous and metamorphic events at the contact between the Ossa Morena Zone and Central Iberian Zone

\section{Journal Article}

Author(s):

Henriques, Susana; Neiva, Ana M.R.; Ribeiro, M. Luísa; Dunning, Greg R.; Tajčmanová, Lucie

Publication date:

2015-04

Permanent link:

https://doi.org/10.3929/ethz-a-010739433

Rights / license:

In Copyright - Non-Commercial Use Permitted

Originally published in:

Lithos 220-223, https://doi.org/10.1016/j.lithos.2015.02.001 
Funding acknowledgement:

335577 - Interplay between metamorphism and deformation in the Earth's lithosphere (EC)

This page was generated automatically upon download from the ETH Zurich Research Collection. For more information, please consult the Terms of use. 
1 Evolution of a Neoproterozoic suture in the Iberian Massif, Central Portugal:

\section{new $\mathrm{U}-\mathrm{Pb}$ ages of igneous and metamorphic events at the contact between the} Ossa Morena Zone and Central Iberian Zone ${ }^{\mathrm{a}}$ LNEG, Geology Department, Ap.7586, 2720-866 Amadora, Portugal; ${ }^{\mathrm{b}}$ Geosciences Centre, University of Coimbra, 3030-790 Coimbra, Portugal cEarth Sciences Department and Geosciences Centre, University of Coimbra, 3030-790 Coimbra, Portugal ${ }^{\text {d} E a r t h ~ S c i e n c e s ~ D e p a r t m e n t, ~ M e m o r i a l ~ U n i v e r s i t y, ~ S t . ~ J o h n ’ s ~ N L ~ A 1 B ~ 3 X 5 ~ C a n a d a ~}$ ${ }^{\text {e} D e p a r t m e n t ~ o f ~ E a r t h ~ S c i e n c e s, ~ E T H Z, ~ C l a u s i u s s t r a s s e ~ 25, ~ C H-8092, ~ Z u r i c h, ~ S w i t z e r l a n d ; ~}$ *Corresponding author at: LNEG, Geology Department, Ap.7586, 2720-866 Amadora, Portugal. Tel.: +351 210924600; fax: +35 1214719018

E-mail addresses: sbahgeo@gmail.com (S.B.A. Henriques), neiva@dct.uc.pt (A.M.R. Neiva), luisacarvalhoduarte@gmail.com (M.L. Ribeiro), gdunning@mun.ca (G.R. Dunning), lucataj@gmail.com (L. Tajčmanová).

Keywords: Northern Gondwana margin, Cadomian magmatism, $P-T$ thermodynamic modelling, ID-TIMS U-Pb geochronology, Sr-Nd isotopes.

Abstract: A Neoproterozoic suture is exposed at the contact between the Ossa Morena Zone and the Central Iberian Zone, in the Iberian Massif (Central Portugal), the westernmost segment of the European Variscides. Although, the Cadomian magmatic and tectonometamorphic events have been previously documented, their timing is still poorly constrained, particularly in the inner zones of the suture. We used geochronological (IDTIMS U-Pb) data to establish the sequence of events, isotopic (Rb-Sr, Sm-Nd) data to 
characterize the magmatic sources and thermodynamic modelling to determine the maximum $P$ - $T$ conditions attained during the Cadomian metamorphism. The first event, in the future Ossa Morena Zone, is the onset of island arc magmatism represented mainly by tholeiites with a MORB signature. Their igneous crystallization age is unknown, but they are older than ca. 539 Ma. This magmatic activity was accompanied by deposition of fine-grained sediments in a Neoproterozoic basin. The second event is the evolution of the Cadomian magmatic arc in different stages. The earliest magmatic stage occurs at ca. $692 \mathrm{Ma}$, which is the oldest igneous age known in the Ossa Morena Zone. It is followed by the generation of subalkaline and peraluminous protoliths at ca. $569 \mathrm{Ma}$, with the isotopic signature of old crustal sources. The final phase of the arc magmatism (ca. 548-544 Ma) involved mainly partial melting of continental crust. The range of the main magmatic activity must have been between ca. 569 Ma and ca. $544 \mathrm{Ma}$ as mentioned for other areas in the Ossa Morena Zone. A major metamorphic event, recorded in metamorphic monazite, zircon and titanite at ca. $540 \mathrm{Ma}$, attained upper amphibolite facies conditions close to the transition to granulite facies (7-8 kbar and $640-660^{\circ} \mathrm{C}$ ). It represents the continental arc accretion of the Ossa Morena Zone with the Iberian Autochthon passive margin (future Central Iberian Zone). The Early Ordovician rocks (ca. 483-477 Ma) were generated from depleted and juvenile sources. These rocks are strongly deformed and with melting features, display metamorphism at amphibolite facies conditions. They are interpreted as related with the Rheic Ocean.

\section{Introduction}

The recognition of Neoproterozoic sutures and the knowledge of their early history are crucial to understanding Gondwana assembly and its dynamics, allowing us to constrain the timing of collisional events. Gondwana assembly constitutes a significant part of Neoproterozoic 
geologic history. Fragments of this evolution are documented in different areas of the Appalachian-Variscan orogen of North America and southern Europe where a major Neoproterozoic suture has been recognized (e.g. Murphy et al., 2006 and references therein). In the Iberian Massif, Western Europe, this suture is preserved within the Tomar-BadajozCórdoba Shear Zone (Fig. 1a), at the contact between the Ossa Morena and Central Iberian Zones (e.g. Eguíluz et al., 2000; Ribeiro et al., 1990). Several authors have recognized a complex evolution, as a result of the superposed Cadomian and Variscan orogenic cycles (e.g. Eguíluz et al., 2000; Quesada and Munhá, 1990; Ribeiro et al., 2009). The age of the amalgamation and suturing process is controversial owing to very intense structural and metamorphic overprinting together with still scarce geochronological data (López-Guijarro et al., 2008). Previous studies of the area include geological sketch maps (Conde, 1984; Gonçalves in Teixeira, 1981; Pereira et al., 1998; Ribeiro et al., 2013) and 1: 50000 geological maps published by the Portuguese Geological Survey (Romão and Esperancinha, 2000; Romão, 2006; Zbyszewski et al., 1981, 1983). The tectonostratigraphic sequence has been established. These authors recognized the occurrence of a Precambrian basement based on field evidence without geochronological data. This study establishes a new tectonostratigraphic sequence based on detailed mapping, petrography, ID-TIMS U-Pb geochronology and whole rock isotopic ( $\mathrm{Rb}-\mathrm{Sr}, \mathrm{Sm}-\mathrm{Nd})$ data. These data are used to constrain the timing of the magmatic and tectonometamorphic events at the northern margin of Gondwana, providing important information for the understanding of Gondwana assembly and the constraints they imposed on the subsequent events that led to the assembly of Pangea.

\section{Geological setting and petrography}


The Iberian Massif represents the westernmost segment of the European Variscides. It was first subdivided into different tectonostratigraphic units by Lotze (1945) and later modified by several authors (e.g. Julivert et al., 1972; Ribeiro et al., 2010a). The studied area is located at the contact between the Ossa Morena Zone and the Central Iberian Zone, within the TomarBadajoz-Córdoba Shear Zone (Fig. 1a). The Ossa Morena Zone was formed along the West African craton margin by recycling of ancient West African crust whereas the Central Iberian Zone, was formed either along the Amazonian margin of Gondwana by recycling of Avalonian and older Amazonian basement (Nance et al., 2008) or near north-east Africa zones by recycling of Saharan metacraton or Arabian-Nubian shield basement (Bea et al., 2010; Villaseca et al., 2011).

The tectonostratigraphic sequence established in this study corresponds to a lower limb of an overturned fold (Fig. 1c). It comprises the following units from bottom to top: the Série Negra Unit, the Sardoal Complex and the Mouriscas Complex. They have a NW-SE direction and are bounded by thrust faults (Fig. 1b). These units belong to the Ossa-Morena zone and were transported towards the NE, on top of the (low-grade and relatively autochthonous) CentralIberian Zone during the Variscan orogeny (Fig. 1c). The amount of the Variscan NE thrust displacement is at least 5 to $10 \mathrm{~km}$ (Ribeiro et al., 2010b).

\subsection{Série Negra Unit}

The Série Negra Unit is a volcano-sedimentary succession, deformed and metamorphosed under variable P-T conditions (Alía, 1963; Carvalhosa, 1965; Eguíluz et al., 2000). It is recognized in southern Portugal and in Spain (e.g. Eguíluz et al., 2000; Pereira et al., 2006) and it has an equivalent in the Bohemian Massif (Linnemann et al., 2008). It is considered to have been deposited in a back arc basin of Ediacaran age (ca. 590-550 Ma) (e.g. Linnemann et 
al., 2008 and references therein). In Spain (Monesterio Antiform) two different sequences were distinguished within the Série Negra: a lower one, the Montemolín succession and an upper one, the Tentudía succession (Eguíluz, 1987). Quesada (1990a, 1990b, 1997, 2006) interpreted the Montemolín succession as a passive margin sequence, whereas the Tentudía succession would represent the infill of a back arc basin.

In the studied area, the Série Negra comprises metavolcanic rocks, metavolcaniclastic rocks, metagreywacke, phyllite, quartz-phyllite, schists (micaschist, quartz-mica schist, quartzofeldspathic schist) with interbedded black chert, greenschist and amphibolite and rhyodacite intrusions (Fig. 1b). The greenschists and amphibolites occur as lenticular bodies oriented parallel to the host rock foliation planes. They are dark-green and fine-grained. The protoliths of the amphibolite have a tholeiitic character with island arc affinity and transitional-alkalic character with an intra-plate signature (Henriques, 2013). The metamorphism and mostly the intense deformation of the lithologies make difficult any stratigraphic linear correlation with the successions established in the southeastern part of the Ossa Morena Zone.

\subsection{Sardoal Complex}

The Sardoal Complex consists of deformed metamorphic rocks mostly of igneous origin: quartzo-feldspathic schist, felsic orthogneiss, migmatite, gneissic granite, interbedded amphibolite and amphibolitic gneiss (Fig. 1b). Minor Carboniferous rhyodacites have intruded these lithologies (Fig. 1b). The quartzo-feldspathic schist shows a pronounced foliation and locally contains coarser and light colored interbedded layers resembling gneissic banding. It contains medium- to coarse-grained porphyroclasts of oligoclase and rare Kfeldspar in a foliated matrix of quartz, oligoclase, biotite and muscovite. Muscovite is overgrowing fibrolitic sillimanite. Accessories are almandine, tourmaline, ilmenite, rutile, 
zircon, monazite and apatite. Secondary phases include albite and epidote. Mylonitic fabric and folded foliation are common. Sardoal Complex orthogneisses were grouped according to location and field relationships. All orthogneisses exhibit intensive deformation features like folded foliation and mylonite. In thin section, porphyroclastic textures are observed and deformation features are common. They include mylonitic fabric, S-C fabrics, ribbon quartz, porphyroclast granulation, rounded porphyroclasts, grain-size reduction and kink-band folds (Fig. 2a). Orthogneisses have variable K-feldspar abundances and different accessory mineral contents (Appendix 1). The Souto orthogneiss is located in the northwest area of the reservoir (Fig. 1b) and is associated with the quartzo-feldspathic schist. It is medium- to coarse-grained and contains quartz, oligoclase, biotite, muscovite and rarely K-feldspar. Accessory minerals include almandine, fibrolitic sillimanite, zircon, tourmaline, ilmenite, rutile, monazite and apatite. The Carvalhal orthogneiss is observed in the Tagus river banks, in the southeast of the area (Fig. 1b). It has a well- defined banded structure, where dark-colored biotite-muscovite layers are deflected around light-colored quartzo-feldspathic layers (Fig. 2b). This orthogneiss is in close association with migmatite, which displays a wide range of structures like schollen structures, biotite schlieren and stromatic structures usually folded (Fig. 2c). The Carvalhal orthogneiss is fine-grained and contains quartz, oligoclase, andesine, orthoclase, perthitic microcline, biotite and muscovite. Accessory minerals include almandine, tourmaline, zircon, ilmenite, apatite, monazite, rutile and magnetite. Chlorite occurs as a secondary mineral. The Sardoal orthogneiss crops out in the area located southeast of the reservoir (Fig. 1b) and frequently exhibits augen textures. It is associated with gneissic granite that contains abundant restitic lithoclasts, biotite restites and quartz rods. The Sardoal orthogneiss is coarse-grained and consists of quartz, oligoclase, K-feldspar, biotite and muscovite. Accessory minerals are fibrolite (Fig. 2d), tourmaline, zircon, apatite, ilmenite, magnetite, rutile and pyrite. Chlorite results from the alteration of biotite. The Olalhas orthogneiss occurs in the Olalhas klippe 
(Ribeiro et al., 2013), located in the northwest of the area (Fig. 1b). It is fine- to mediumgrained and comprises quartz, oligoclase, biotite, muscovite and rare K-feldspar. Accessory minerals include sillimanite, staurolite, almandine, tourmaline, zircon, ilmenite, apatite and pyrite. Staurolite and sillimanite are enclosed in muscovite (Fig. 2e). The minerals of the orthogneiss were reequilibrated, particularly biotite and muscovite, whereas the plagioclase reequilibration was less intense (Henriques, 2013). The protoliths of the orthogneiss were calc-alkaline, peraluminous and had granitic and granodioritic compositions. They were generated in an active continental margin as indicated by their chemical compositions: enrichments in LILE compared to HFSE; high $\mathrm{Nb}_{\mathrm{N}} / \mathrm{Yb}_{\mathrm{N}}=3.98$ to 17.91 ; negative anomalies in $\mathrm{P}_{2} \mathrm{O}_{5}$ and $\mathrm{TiO}_{2}$ (e.g. Wilson, 1989) and $\mathrm{Th} / \mathrm{Ta}$ ratios (5.96 to 17.23) and $\mathrm{Yb}$ values (0.96), that fall in the range of values for active continental margins from Gorton and Schandl (2000) (Henriques et al., 2006; Henriques et al., 2010a; Henriques, 2013). Thermodynamic modelling indicates metamorphism at amphibolitic facies conditions (4-4.5 kb and 570-590 C) (Henriques et al., 2013).

In the Sardoal Complex, elongate metre-size bodies of amphibolite and amphibolitic gneiss occur interbedded in the orthogneiss. The Cabeço da Moura amphibolite, located in the Olalhas klippe (Fig. 1b), is dark and fine-grained. In thin section, it displays foliated granoblastic to nematoblastic textures and consists of magnesiohornblende, labradorite rimmed by andesine, diopside with subordinate ilmenite, zircon, titanite, apatite, quartz, magnetite and pyrite. Locally, ferrohornblende, labradorite rimmed by bytownite, augite and rarely ferroedenite are present. The mineralogical association indicates upper amphibolite facies conditions (e.g. Bucher and Frey, 2002). Retrograde minerals include actinolite and epidote. The Vila Nova amphibolite occurs in the remaining Sardoal Complex area (Fig. 1b). It is fine-grained and shows an incipient gneissic banding, where dark layers are enriched in amphibole and light layers are enriched in plagioclase, epidote and carbonate. In thin section, 
foliated granoblastic to nematoblastic textures are observed. The mineral content consists of magnesiohornblende, labradorite rimmed by andesine, diopside with subordinate ilmenite, titanite, apatite, quartz, and pyrite. Actinolite and epidote are retrograde minerals. The Vila Nova amphibolite locally contains pargasite and ferropargasite. The Cabeço da Moura amphibolite shows $\mathrm{N}$ and E-MORB affinities and the Vila Nova amphibolite shows E-MORB affinities in Wood (1980) diagram (Henriques, 2013). Both are mainly tholeiites, according to the ratios established by Pearce (1983), $\mathrm{Th} / \mathrm{Yb}=0.02$ to 0.28 and $\mathrm{Ta} / \mathrm{Yb}=0.06$ to 0.26 . They were generated in an island-arc setting as indicated by the MORB- normalized spider diagram of Pearce (1983), that shows enrichment of LILE relatively to $\mathrm{HFSE}\left(\mathrm{Nb}_{\mathrm{N}} / \mathrm{Yb}_{\mathrm{N}}=0.98\right.$ to 3.57) and a depletion of HFSE relatively to MORB (Henriques et al., 2010b; Henriques, 2013).

\subsection{Mouriscas Complex}

The Mouriscas Complex is a deformed and metamorphosed predominantly mafic igneous complex that consists of amphibolite, protomylonite trondhjemite, garnet amphibolite, metatexite and diatexite. Bodies of amphibolite are fine- to coarse-grained and comprise most of the Complex area. Deformation features, like folded foliation and mylonite, are common. Metamorphic segregation appears as incipient gneissic banding. Rarely relic igneous textures are preserved in some outcrops. Thin sections show preserved igneous texture (Fig. 2f), porphyroclastic texture and mylonitic fabric (Fig. 2g). Amphibolite consists of plagioclase, amphibole and less abundant quartz, biotite, titanite, zircon, tourmaline, apatite, ilmenite, rutile, magnetite and pyrite. Actinolite, epidote and chlorite are retrograde phases. Amphibole is usually zoned: magnesiohornblende rimmed by cummingtonite, ferrotschermakite, tschermakite, and less frequently ferrohornblende. Cummingtonite rimmed by ferrotschermakite and tschermakite is also present. The protoliths of the amphibolites, which 
are plutonic, have basic to intermediate compositions and show calc-alkaline character and intra-plate and continental arc affinities (Henriques, 2013; Ribeiro et al., 1995).

The protomylonite trondhjemite occurs as dykes and massive outcrops. The dykes of metric dimension intruded the Neoproterozoic amphibolites. Protomylonite trondhjemite shows porphyroclastic and cataclastic textures and mylonitic fabric. It consists of porphyroclasts of quartz, oligoclase, muscovite, biotite, almandine, fibrolitic sillimanite and staurolite. The main constituents of the matrix are quartz, oligoclase, biotite, almandine and small amounts of zircon, rutile, ilmenite, monazite, apatite and rare K-feldspar. Secondary minerals are chlorite and muscovite. Estimated $P-T$ conditions using thermodynamic modelling are in the range of 4.5-6.2 $\mathrm{kb}$ and 590-650 $\mathrm{C}$ (Henriques et al., 2013).

Garnet amphibolite crops out as a massive heterogeneous outcrop of decametric dimension. The most distinctive feature is the occurrence of large garnet grains surrounded by lightcolored halos (Fig. 2h). Garnet amphibolite is medium- to coarse-grained and contains plagioclase, amphibole and less abundant almandine, biotite, quartz, epidote, zircon, apatite and ilmenite. Plagioclase is andesine rimmed by oligoclase. Amphibole is grunerite rimmed by ferrotschermakite. Almandine occurs as large irregular porphyroblasts surrounded by quartz, andesine and oligoclase, that cross cut the foliation, indicating post-kinematic recrystallization. The whole rock data indicate protoliths with MORB signatures and crustal contamination (Henriques, 2013; Ribeiro et al., 1995). The garnet amphibolite $P$ - $T$ conditions were estimated using thermodynamic modelling at $6.5 \mathrm{~kb}$ and $550^{\circ} \mathrm{C}$ (Henriques et al., 2013).

\section{Analytical methods}

\subsection{ID-TIMS U-Pb geochronology}


The analytical procedures were performed at the Earth Sciences Department of Memorial University of Newfoundland. A total of 12 rock samples representative of the geological units were collected for ID-TIMS U-Pb analyses (Fig. 1b). The samples (20-30 kg each) were crushed, pulverized and sieved to dimensions $<40$ mesh. Heavy mineral fractions were separated using the Wifley table, heavy liquids and the Frantz magnetic separator. The final fractions were observed under a binocular microscope and the best quality zircon, monazite and titanite were picked for analysis. Cathodo-luminescence images of zircon were obtained on a FEI Quanta 400 SEM. Some of the selected zircon and coarse monazite and titanite crystals were abraded using the Krogh (1982) technique. Zircon from some samples was subjected to annealing, followed by chemical abrasion using the technique of Mattinson (2005). After these procedures a second selection of the best crystals was done to assure the quality of the analyses. Mineral fractions were washed and weighed. Zircon fractions were mixed with a ${ }^{205} \mathrm{~Pb}^{238} \mathrm{U}$ spike (Parrish and Krogh, 1987) and dissolved with distilled HF and distilled $8 \mathrm{~N} \mathrm{HNO}_{3}$ in Krogh-type Teflon ${ }^{\circledR}$ dissolution bombs, that were kept in the oven at a temperature of $220^{\circ} \mathrm{C}$ for 5 days (after Krogh, 1973). Monazite fractions were mixed with a ${ }^{205} \mathrm{~Pb}^{238} \mathrm{U}$ spike and dissolved with distilled 6.2N HCl in a savillex ${ }^{\circledR}$ Teflon container which was heated on a hot plate for 5 days at $120^{\circ} \mathrm{C}$ (Parrish, 1990). Titanite fractions were mixed with a ${ }^{205} \mathrm{~Pb}_{-}{ }^{238} \mathrm{U}$ spike and dissolved with distilled $\mathrm{HF}$ and distilled $8 \mathrm{~N} \mathrm{HNO}_{3}$ in a savillex® Teflon container which was heated on a hot plate for 5 days at $120^{\circ} \mathrm{C}$. $\mathrm{U}$ and $\mathrm{Pb}$ were separated through ion exchange chemistry according to modified procedures for zircon chemistry after Krogh (1973), reducing the volume of the columns and the reagents in a ratio of 1/10, and $\mathrm{HBr}$ chemistry after Manhés et al. (1978) for titanite and monazite. The isotopic ratios were measured in a Finningan MAT 262 thermal ionization mass spectrometer, which includes an ion counting secondary electron multiplier (SEM) detector. U and Pb were loaded together on a previously outgassed Re filament with silica gel and dilute $\mathrm{H}_{3} \mathrm{PO}_{4}$ using the 
technique of Cameron et al. (1969). The mass spectrometer faraday cups were calibrated using a NBS $981 \mathrm{~Pb}$ standard and the SEM was calibrated against a faraday cup by measuring a known isotopic ratio. The isotopic ages were calculated using the decay constants of Jaffey et al. (1977) and an unpublished program. The uncertainties of the isotopic ratios were calculated at $2 \sigma$ using the same software and taking into account the uncertainties of the isotopic ratio measurements, the $\mathrm{U}$ and $\mathrm{Pb}$ fractionation, the laboratory procedure blanks (1$10 \mathrm{pg} \mathrm{Pb}$ ) and the initial common $\mathrm{Pb}$, which was corrected following the model of Stacey and Kramers (1975). The ages were calculated using ISOPLOT (Ludwig, 2003) and uncertainties are reported at the 95\% confidence level. Upper intercept ages for discordia lines were calculated after Davis (1982).

\section{2. $\mathrm{Rb}-\mathrm{Sr}$ and $\mathrm{Sm}-\mathrm{Nd}$ isotopes}

A total of 21 samples were analysed at the Earth Sciences Department of the Memorial University of Newfoundland, St. John's, Canada. For Sm-Nd and Sr analyses approximately 0.05 to $0.2 \mathrm{~g}$ of rock powder was dissolved in Savilex@ Teflon beakers using a mixture of concentrate $\mathrm{HF}-\mathrm{HNO}_{3}$ acids. A mixed ${ }^{150} \mathrm{Nd} /{ }^{149} \mathrm{Sm}$ spike was added to each sample prior to acid digestion. Both sample and spike were weighed on a high-precision balance. After five days of digestion, the solution was evaporated to dryness and then taken up in $6 \mathrm{~N} \mathrm{HCl}$ acid for two days. The solution was then dried and taken up in $2.5 \mathrm{~N} \mathrm{HCl}$ and loaded on cationic exchange AG50W - X8 resin to separate the REE and Sr fractions. The Sm and Nd were then separated using a secondary column loaded with Eichrom@ $\odot$ Ln resin, while Sr was purified and recuperated using a $1 \mathrm{~mL}$ column filled with Eichrom@ $\odot \mathrm{Sr}$ spec. resin. All reagents were distilled and blank levels are ca. 100 -200 pg for Nd. All isotopic ratios were obtained using a multicollector Finnigan Mat 262 mass spectrometer in static mode. The Nd and Sr isotopic ratios were normalized to ${ }^{146} \mathrm{Nd} /{ }^{144} \mathrm{Nd}=0.721903$ and ${ }^{88} \mathrm{Sr} /{ }^{86} \mathrm{Sr}=8.375209$ respectively. The 
reported ${ }^{143} \mathrm{Nd} /{ }^{144} \mathrm{Nd}$ and ${ }^{87} \mathrm{Sr} /{ }^{86} \mathrm{Sr}$ ratios were corrected for the deviation from repeated measurements of the JNdi-1 $\left({ }^{143} \mathrm{Nd} /{ }^{144} \mathrm{Nd}=0.512115\right.$, Tanaka et al., 2000) and NBS 987 $\left({ }^{87} \mathrm{Sr} /{ }^{86} \mathrm{Sr}=0.710340\right)$ standards. During the course of data acquisition, replicates of the standards gave a mean value of ${ }^{143} \mathrm{Nd} /{ }^{144} \mathrm{Nd}=0.512137 \pm 19$ (Stedv, $\mathrm{n}=112$ ) for JNdi-1 and ${ }^{87} \mathrm{Sr} /{ }^{86} \mathrm{Sr}=0.710291 \pm 25$ (Stedv, $\mathrm{n}=46$ ) for NBS 987. In-run precisions on all isotopic ratios are given at 95\% confidence level. Errors on $\mathrm{Nd}$ and $\mathrm{Sr}$ isotopic compositions are $<0.002 \%$ and errors on the ${ }^{147} \mathrm{Sm} /{ }^{144} \mathrm{Nd}$ ratio are estimated to be less than $0.1 \%$. The $\varepsilon \mathrm{Nd}$ values were calculated using values of ${ }^{147} \mathrm{Sm} /{ }^{144} \mathrm{Nd}=0.1967$ and ${ }^{143} \mathrm{Nd} /{ }^{144} \mathrm{Nd}=0.512638$ for the present day chondrite uniform reservoir (CHUR). ${ }^{147}$ Sm decay constant is $6.54 \times 10^{-12} \mathrm{y}^{-1}$ (Steiger and Jäger, 1977). $\mathrm{T}_{\mathrm{DM}}$ is calculated with respect to the DePaolo (1981a) mantle model and also using a linear evolution for a mantle separated from the CHUR at $4.55 \mathrm{Ga}$ and having a present day $\varepsilon N d$ value of $+10\left(\mathrm{~T}_{\mathrm{DM} 2}\right)$.

\subsection{Electron microprobe analyses}

Mineral analyses were performed on an electronic microprobe CAMECA SX-100, at Oviedo University, Spain, with a $15 \mathrm{kV}$ accelerating voltage, $15 \mathrm{nA}$ beam current, $5 \mu \mathrm{m}$ beam diameter and peak counting times of $10 \mathrm{~s}$ for most elements except for V (20 s), Co and Ni (5 s). Some of the mineral analyses were carried out on an electron microprobe Jeol $8500-\mathrm{F}$ at Laboratório Nacional de Energia e Geologia (LNEG), Portugal, with a 15 kV accelerating voltage, $15 \mathrm{nA}$ beam current, $5 \mu \mathrm{m}$ beam diameter and $15 \mathrm{~s}$ peak counting times. The detection limit is variable according to the element, but generally higher than $200 \mathrm{ppm}$ and the accuracy is better than $2 \%$. ZAF corrections were applied.

\section{ID-TIMS U-Pb geochronology}


Sample 321-140 is from a quartzo-feldspathic schist (Appendix 1). This sample contains flat euhedral medium to large yellow monazite and euhedral, clear, colorless, medium to large (2:1) zircon prisms. The oldest monazite fraction (M1) provided a ${ }^{207} \mathrm{~Pb} /{ }^{235} \mathrm{U}$ age of $540 \pm 3$ Ma (95\%CI) and the weighted average ${ }^{207} \mathrm{~Pb} /{ }^{235} \mathrm{U}$ age of $\mathrm{M} 1$ and $\mathrm{M} 2$ is $538 \pm 2 \mathrm{Ma}$ (MSWD=0.92, 95\%CI), which is interpreted as the age of the metamorphic event (Fig. $4 \mathrm{~b}$, Table 1a). M3 is younger and also overlaps Concordia. It is interpreted likely to have a thin rim of Variscan age. The CL images show zoned zircon (Fig. 3a, b) that in some cases present dissolution surfaces and evidence of late metamorphism in the rim (Fig. 3b). Six zircon analyses (Z1-Z3 and Z6-Z8) define a discordia line anchored at a lower intercept at $540 \pm 3$ Ma age and giving an upper intercept age of $692+77 /-60$ Ma, with a probability of fit of $8 \%$ (Fig. 4b, Table 1a). The isotopic systematics of this group of zircon analyses suggests that the age of $692 \mathrm{Ma}$ is the age of the protolith which was likely an igneous rock. Two zircon analyses (Z4 and Z5) are highly discordant indicating an inherited component in these grains (Fig. 4a, Table 1a).

Sample gn is from a Carvalhal orthogneiss (Appendix 1). This sample contains subhedral, medium yellow monazite and euhedral, clear, sharp, colorless, medium to large (2:1) zircon prisms. Four monazite analyses provided four concordant data points that show some scatter along the Concordia curve, the oldest one (M2) has a ${ }^{207} \mathrm{~Pb} /{ }^{235} \mathrm{U}$ age of $540 \pm 5 \mathrm{Ma}(95 \% \mathrm{CI})$ which is interpreted as the age of metamorphism (Fig. 4d, Table 1a). Younger monazite fractions (M1, M3, M4) all overlap the Concordia but are interpreted to be composite and on a mixing line to a Variscan metamorphic overprint (Fig. 4d). The CL images show growth 
zoning in euhedral zircon (Fig. 3c), some of which contain subrounded cores (Fig. 3d). Triplicate concordant analyses of zircon prisms (Z6, Z10, Z12) yield a weighted average ${ }^{206} \mathrm{~Pb} /{ }^{238} \mathrm{U}$ age of $569 \pm 3 \mathrm{Ma}(\mathrm{MSWD}=0.33$, 95\% CI), which is interpreted as the igneous crystallization age of the protolith granite (Fig. 4d, Table 1a). Analyses Z7, Z8, Z13 and Z14, which are concordant or near concordant at older ages, are interpreted to represent composite grains with igneous rims and older cores (Fig. 4d, Table 1a). There are also inherited Neoarchean zircons, with ${ }^{207} \mathrm{~Pb} /{ }^{206} \mathrm{~Pb}$ ages of $2801 \mathrm{Ma}$ (Z11) and of $2755 \mathrm{Ma}$ (Z5) and several analyses with inherited Proterozoic zircon (Z1-Z4) defining a line with a lower intercept age at $569 \pm 3 \mathrm{Ma}$ (the most likely age of the rims) and an upper intercept at $1905 \pm 85 \mathrm{Ma}$ (Fig. 4c, Table 1a). This might be the age of a significant amount of material in the source region, either just detrital zircons, or perhaps actual basement orthogneiss of this age.

Sample 10 is from a Sardoal orthogneiss (Appendix 1). This sample contains clear, sharp, colorless, euhedral (3:1) large zircon prisms. The CL images show well preserved concentric oscillatory growth zoning (Fig. 3e, f). Four analyses (Z2, Z4, Z6, Z7) are slightly discordant and have a weighted average ${ }^{207} \mathrm{~Pb} /{ }^{206} \mathrm{~Pb}$ age of $548 \pm 4$ Ma (MSWD=0.08, 95\%CI), which is interpreted as the age of igneous crystallization of the protolith (Fig. 4e, Table 1a). Fractions Z1, Z3 and Z5 are discordant and interpreted to contain inherited older zircon components (Fig. 4e, Table 1a).

Sample 311-56 is from a Souto orthogneiss (Appendix 1). This sample contains subhedral medium to large monazite and subhedral to euhedral, clear, colorless, medium to large zircon prisms (2:1) with tapered ends. The oldest monazite fraction (M2) provides a ${ }^{207} \mathrm{~Pb} /{ }^{235} \mathrm{U}$ age of $539 \pm 2 \mathrm{Ma}(95 \% \mathrm{CI})$ (Fig. 4g, Table 1a) and is interpreted as the age of metamorphic event. The monazite data points are slightly "reversely" discordant (Fig. 4g) which is related 
to the incorporation during crystallization of excess amounts of ${ }^{230}$ Th (Parrish, 1990; Schärer, 1984). The zircon CL images show zoned zircon (Fig. 3g) around cores (Fig. 3h). One zircon fraction (Z3) is slightly discordant and two zircon fractions (Z1 and Z2) are highly discordant indicating the presence of inheritance (Fig. 4f, g, Table 1a).

Sample 311-30 is from a Olalhas orthogneiss (Appendix 1). This sample contains euhedral, colorless, medium to large (3:1) zircon prisms with tapered ends. The CL images show igneous and inherited zircons with evidence of late recrystallization (Fig. 3i, j). Four zircon multigrain fractions provided discordant data points (Fig. 4h, Table 1a) interpreted to reflect inheritance, also supported by CL images. Analysis Z3 is close to the Concordia curve with a ${ }^{206} \mathrm{~Pb} /{ }^{238} \mathrm{U}$ age of $597 \mathrm{Ma}$ (Fig. 4h, Table 1a) whereas $\mathrm{Z1}$ contains a component with ${ }^{207} \mathrm{~Pb} /{ }^{206} \mathrm{~Pb}$ age of $1696 \mathrm{Ma}$ (Fig. 4h, Table $\left.1 \mathrm{a}\right)$.

Sample 311-1 is from a Cabeço da Moura amphibolite (Appendix 1). This sample contains two zircon populations. The first one consists of clear, colorless, small equant multi-faceted «soccer-ball» zircon. The other one consists of clear, colorless, subhedral, long prisms with rounded ends. The «soccer-ball» zircon CL images (Fig. 3k, l) show fir-tree type and radial sector zoning. The external morphology of «soccer-ball» zircons and their internal texture indicate they are metamorphic zircon that crystallized at upper amphibolite/granulite grades (e.g. Hoskin and Schaltegger, 2003 and references therein). Three multi-grain zircon fractions of small equant multi-faceted «soccer-ball» provided three data points (Z1, Z2, Z4) with a weighted average ${ }^{206} \mathrm{~Pb} /{ }^{238} \mathrm{U}$ age of $539 \pm 3$ Ma (MSWD=0.20, 95\%CI), which is interpreted as the age of the peak of metamorphism (Fig. 4i, Table 1a). One single long zircon prism 
provided a slightly discordant data point (Z3) that probably reflects some inheritance of $\mathrm{Pb}$ (Fig. 4i, Table 1a).

Sample 311-62 is from a Vila Nova amphibolite (Appendix 1). This sample contains a population of medium clear subhedral brown titanite. Two titanite fractions provided a weighted average ${ }^{206} \mathrm{~Pb} /{ }^{238} \mathrm{U}$ age of $529 \pm 5 \mathrm{Ma}(\mathrm{MSWD}=0.018,95 \% \mathrm{CI}$ ), which is interpreted as the age of cooling through the blocking temperature for titanite after the ca. 539 Ma peak of metamorphism (Fig. 4j, Table 1a).

\subsection{Mouriscas Complex}

Sample 321-138 is from an amphibolite that shows relic igneous texture (Appendix 1). Zircon in this sample consists of medium to large square cross-section prism fragments plus prisms and large cross-section (3:1) prisms. The CL images show banded zoning common in mafic rocks such as hornblende gabbro or diorite (Hoskin, 2000) (Fig. 3m). Three zircon fractions provided overlapping concordant data points, with a weighted average ${ }^{206} \mathrm{~Pb} /{ }^{238} \mathrm{U}$ age of 544.2 $\pm 1.7 \mathrm{Ma}$ (MSWD=0.66, 95\% CI), which is interpreted to be the time of igneous crystallization (Fig. 5a, Table 1b).

Sample 58A is amphibolite that shows granofelsic texture (Fig. 2f, Appendix 1). This sample contains two populations of zircon: one euhedral, clear, sharp, colorless, needle prisms and another euhedral to subhedral, colorless, medium to large (2:1) prisms. The CL images of both zircon populations show a banded zoning pattern (Fig. 3n). Evidence for a late metamorphic event is suggested by subrounded contours. Three multi-grain fractions containing medium-large (2:1) prisms provide overlapping concordant data points with a 
weighted average ${ }^{207} \mathrm{~Pb} /{ }^{206} \mathrm{~Pb}$ age of $544.3 \pm 2.5 \mathrm{Ma}$ (MSWD=0.054; 95\%CI), which is interpreted to be the time of igneous crystallization (Fig. 5b, Table 1b).

Sample 321-M is from an amphibolite that shows porphyroclastic texture and mylonitic fabric (Fig. 2g, Appendix 1). This sample contains clear, colorless, euhedral (2:1) very large zircon prisms. The CL images show zoned zircons with banded zoned cores (Fig. 3o). Two multigrain fractions provided concordant or slightly discordant data points with a weighted average ${ }^{207} \mathrm{~Pb} /{ }^{206} \mathrm{~Pb}$ age of $544 \pm 2 \mathrm{Ma}$ (MSWD=0.098; 95\%CI), which is interpreted to be the time of igneous crystallization (Fig. 5c, Table 1b).

Sample 165 is from a protomylonite trondhjemite (Appendix 1). This sample contains medium to small, euhedral to subhedral, clear, yellow monazite and medium, euhedral to subhedral, simple, clear, colorless to light yellow, (2:1) zircon prisms and large angular fragments. The zircon CL images show regular growth zoning, sector and oscillatory zoning patterns, (Fig. 3p, q), minor recrystallization (Fig. 3q) and cores (Fig. 3r). Three small monazite multi-grain fractions provided points that are 3 to 10\% discordant (Fig. 5d, Table 1b). They are co-linear with the concordant zircon fraction Z3 and define a discordia line anchored at $10 \pm 10 \mathrm{Ma}$, with an upper intercept age of $484 \pm 10 \mathrm{Ma}$ (probability of fit=71\%, 95\%CI). The ${ }^{206} \mathrm{~Pb} /{ }^{238} \mathrm{U}$ age of $\mathrm{Z3}$ is $483 \pm 1.5 \mathrm{Ma}$ and this is the best estimate of the age of igneous crystallization (Fig. 5d, Table 1b). Three other zircon fractions containing single (Z4) or multigrain euhedral (2:1) prisms (Z1, Z2) yield older ages (Table 1b) that are interpreted to be due to an inherited component (Fig. 3r).

Sample 20A is from a garnet amphibolite (Appendix 1). This sample contains large, euhedral, clear, sharp, colorless to light yellow (2:1) zircon prism fragments. The CL images show 
banded zoning and recrystallization (Fig. 3s). Seven zircon fractions containing multigrain, large (2:1) prism fragments provided 2 slightly discordant points (Z1 and Z3) and 5 overlapping concordant points (Z2, Z4-Z7) that define a weighted average ${ }^{206} \mathrm{~Pb} /{ }^{238} \mathrm{U}$ age of $477 \pm 2$ Ma (MSWD=0.17, 95\%CI), which is interpreted to be the age of igneous crystallization (Fig. 5e, Table 1b).

\section{5. $\mathrm{Rb}-\mathrm{Sr}$ and Sm-Nd results}

Results are listed in Tables 2a and 2b. The Sr and Nd initial ratios and initial $\varepsilon N d$ values $\left(\varepsilon N d_{t}\right)$ were calculated using the corresponding U-Pb igneous ages for samples 321-140, gn, 10, 58A, 321-138, 321-M, 165 and 20A. For other samples, igneous ages were assumed based on identical features of dated samples, such as field relationships, petrography, mineral content and geochemical signatures. The $\mathrm{T}_{\mathrm{DM}}$ model age is interpreted as the average crustal residence time (Arndt and Goldstein, 1987; Murphy and Nance, 2002).

\subsection{Sardoal Complex}

The $\mathrm{Sr}$ initial ratio and the $\varepsilon \mathrm{Nd}_{\mathrm{t}}$ values allow us to discriminate various groups of orthogneiss (Fig. 6). The Souto orthogneiss (ca. $692 \mathrm{Ma}$ inferred) has $\left({ }^{87} \mathrm{Sr} /{ }^{86} \mathrm{Sr}\right)_{\mathrm{i}}=0.7057$ and 0.7060 , $\varepsilon \mathrm{Nd}_{\mathrm{t}}=-5.2$ to -7.3 and plot within the fields of metasedimentary lower crust and meta-igneous lower crust (Tables 2a, b, Fig. 6). $\mathrm{T}_{\mathrm{DM}}$ model ages range between 1.60 and $1.65 \mathrm{Ga}$ (Table 2b). The Carvalhal orthogneiss (ca. $570 \mathrm{Ma})$ has $\left({ }^{87} \mathrm{Sr} /{ }^{86} \mathrm{Sr}\right)_{\mathrm{i}}=0.7077-0.7096, \varepsilon \mathrm{Nd}_{\mathrm{t}}=-6.0$ to 8.1 (Tables 2a, b) and plot within the fields of metasedimentary lower crust and meta-igneous middle-upper crust (Fig. 6). They yield $\mathrm{T}_{\mathrm{DM}}$ model ages from 1.53 to $1.69 \mathrm{Ga}$ (Table 2b). The Sardoal orthogneiss (ca. $548 \mathrm{Ma}$ ) shows $\left({ }^{87} \mathrm{Sr}{ }^{86} \mathrm{Sr}\right)_{\mathrm{i}}=0.7092$ to $0.7117, \varepsilon \mathrm{Nd}_{\mathrm{t}}=-5.9$ to -6.4 
and plots within the field of meta-igneous middle-upper crust and show $\mathrm{T}_{\mathrm{DM}}$ model ages from 1.56 to 1.65 Ga (Tables 2a, b, Fig. 6). The Olalhas orthogneiss shows $\mathrm{T}_{\mathrm{DM}}$ model ages from 1.48 to $1.56 \mathrm{Ga}$ (Table 2b). These data suggest that the various units of orthogneiss are hybrid rocks and their protoliths were generated from melting of different crustal sources. All the orthogneiss units present old $\mathrm{T}_{\mathrm{DM}}$ model ages, indicating a strong component of old crustal rocks (e.g. López-Guijarro et al., 2008).

\subsection{Mouriscas Complex}

The protoliths of the bodies of amphibolite (ca. $544 \mathrm{Ma}$ ) are presumed to have been coarsegrained intrusions likely gabbro or diorite, based on the grain size and morphology of zircon. These samples show heterogeneous $\left({ }^{87} \mathrm{Sr} /{ }^{86} \mathrm{Sr}\right)_{\mathrm{i}}$ isotopic signatures (0.7053 to 0.7084) (Table 2a). Most samples show $\varepsilon \mathrm{Nd}_{\mathrm{t}}$ negative values suggesting crustal contamination (-2.9 to -3.4$)$ and plot within the field of mantle array and meta-igneous lower crust (Table 2b, Fig. 6), but sample 311-96A plots within the field of meta-igneous middle-upper crust (Fig. 6). The sample 58A shows a $\varepsilon \mathrm{Nd}_{\mathrm{t}}$ positive value (3.2) and plots within the field of lithospheric mantle (Table 2b, Fig. 6). All samples exhibit old $\mathrm{T}_{\mathrm{DM}}$ model ages from 1.22 to $1.81 \mathrm{Ga}$ (Table 2b). Protoliths of protomylonite trondhjemite (са. $483 \mathrm{Ma}$ ) show a narrow range of isotopic compositions with $\left({ }^{87} \mathrm{Sr} /{ }^{86} \mathrm{Sr}\right)_{\mathrm{i}}=0.7039$ to 0.7045 and $\varepsilon \mathrm{Nd}_{\mathrm{t}}=5.0$ to 5.3, compatible with the field of lithospheric mantle (Tables 2a, b, Fig. 6). $\mathrm{T}_{\mathrm{DM}}$ model ages are identical in all samples and range from 0.61 to 0.65 Ga (Table 2b), suggesting a rather juvenile source. Protoliths of garnet amphibolite (ca. $477 \mathrm{Ma}$ ) show heterogeneous isotopic compositions: one has $\left({ }^{87} \mathrm{Sr} /{ }^{86} \mathrm{Sr}\right)_{\mathrm{i}}=0.7030, \varepsilon \mathrm{Nd}_{\mathrm{t}}=8.2$ and plots within the field of MORB; the other has $\left({ }^{87} \mathrm{Sr} /{ }^{86} \mathrm{Sr}\right)_{\mathrm{i}}$ $=0.7042, \varepsilon \mathrm{Nd}_{\mathrm{t}}=6.7$ and plots within the field of lithospheric mantle (Tables 2a, b, Fig. 6). Young $\mathrm{T}_{\mathrm{DM}}$ model ages $(0.34$ to $0.52 \mathrm{Ga})$ indicate juvenile sources in both cases (Table $\left.2 \mathrm{~b}\right)$. 


\section{6. $P$-T calculation}

Representative electron microprobe analyses of minerals from sample 311-1, Cabeço da

Moura amphibolite (Sardoal Complex), are presented in Appendix 2. The amphibolite is fine-

481

482

483

484

485

486

487

488

489

490

491

492

493

494

495

496

497

498

499

grained, displays granoblastic to nematoblastic textures and contains the following mineral assemblage: $\operatorname{mg}-\mathrm{hbl}(\mathrm{am})+(\mathrm{lab}+\mathrm{byt}) \mathrm{pl}+\mathrm{di}(\mathrm{cpx})+\mathrm{zrn}+\mathrm{qtz}+\mathrm{ilm}+\mathrm{ttn}$. Amphibole shows $\mathrm{X}_{\mathrm{Mg}}$ values of $0.60-0.62$, plagioclase $X_{\text {An }}$ contents of $0.65-0.75$ and diopside $X_{W_{0}}=0.47-0.48$. The $P-T$ diagram was computed using the Perple_X program (Connolly, 2009) and the thermodynamic dataset of Holland and Powell (1998, revised 2003). The bulk rock composition used for the calculations is in mol\%, as is indicated in the $P-T$ diagram. The following solution models where used: amphibole (Dale et al., 2005), clinopyroxene (Green et al., 2007), chlorite, epidote and garnet (Holland and Powell, 1998), ilmenite and magnetite (Anderson and Lindsley, 1988), orthopyroxene (Holland and Powell, 1996), plagioclase (Newton et al., 1980). Quartz, rutile and titanite were considered as pure phases. Calculations were made for NCFMASHTO $\left(\mathrm{Na}_{2} \mathrm{O}, \mathrm{CaO}, \mathrm{FeO}, \mathrm{MgO}, \mathrm{Al}_{2} \mathrm{O}_{3}, \mathrm{SiO}_{2}, \mathrm{TiO}_{2}, \mathrm{H}_{2} \mathrm{O}, \mathrm{O}_{2}\right)$ model chemical system with water and quartz in excess. The $P$ - $T$ conditions were estimated based on the compositional isopleths for key mineral phases in the observed stability field (Cpx-Am-PlIlm-Ttn) at $7-8 \mathrm{kbar}$ and $640-660^{\circ} \mathrm{C}$, amphibolite facies conditions close to the transition to granulite facies (Fig. 7).

\section{Discussion}

\subsection{Neoproterozoic magmatism}


Evidence for island arc magmatism is provided by the Série Negra and Sardoal Complex amphibolite. Both show tholeiitic character (Henriques, 2013), suggesting that they were generated in early stages of the arc (Wilson, 1989). Other protoliths of Série Negra amphibolite have transitional-alkalic character with an intra-plate signature, suggesting a more advanced stage of the arc (Wilson, 1989). The Sardoal Complex amphibolite protoliths, older than ca. 539 Ma, (Fig. 4i), have a MORB signature and were generated from depleted and enriched mantle sources (Henriques, 2013). The existence of an island arc was also recognized in other areas of the Ossa Morena Zone (e.g. Ribeiro et al., 2003).

The Sardoal Complex orthogneiss units (ca. 692-548 Ma), (Figs. 4a-e), have a calc-alkaline and peraluminous character and were generated from protoliths of acid composition with the geochemical signature of an active continental margin (Henriques, 2013). Their Sr and Nd initial isotopic signatures, $\left({ }^{87} \mathrm{Sr} /{ }^{86} \mathrm{Sr}\right)_{\mathrm{i}}=0.7057-0.7117$ and $\varepsilon \mathrm{Nd}_{\mathrm{t}}=-5.2$ to -8.1 , (Tables 2a, b), indicate partial melting of old metasedimentary and meta-igneous crust at different crustal levels (Fig. 6). This information is supported by the ages of inherited zircon (1.7 Ga-2.8 Ga), (Table 1a). The early rift-related granitoids from the Ossa Morena Zone (ca. 524-516 Ma; Sánchez-García et al., 2014), by contrast, show higher $\varepsilon \mathrm{Nd}_{\mathrm{t}}$ values (-3.6 to -1.8).

The Mouriscas Complex amphibolite bodies, interpreted to have originated as plutonic rocks (ca. 544 Ma), (Figs. 5a-c), have a calc-alkaline character, intermediate and basic compositions with intra-plate and continental arc affinities (Henriques, 2013). Their initial Sr and Nd isotopic signatures of $\left({ }^{87} \mathrm{Sr} /{ }^{86} \mathrm{Sr}\right)_{\mathrm{i}}=0.7053-0.7084$ and $\varepsilon \mathrm{Nd}_{\mathrm{t}}=(-3.6$ to 3.2), (Tables 2a, b) suggest an origin from a mantle source and crustal contamination (Fig. 6).

Negative $\varepsilon \mathrm{Nd}_{\mathrm{t}}$ values and old $\mathrm{T}_{\mathrm{DM}}$ model ages of Neoproterozoic rocks are characteristic of Cadomian-type terranes (e.g. Murphy et al., 2004, Murphy and Nance, 2002) and are identical to those of other areas of the Cadomian orogen, such as the Bohemian Massif and Armorica (Fig. 8) (e.g. Linnemann et al., 2004; Samson et al., 2003). The major igneous event that 
occurred during the Neoproterozoic (са. 692-544 Ma) is interpreted as the progressive evolution of the Cadomian magmatic arc, on continental margin.

Carvalhal orthogneiss (569 \pm 3 Ma), (Fig. 4d), contains Paleoproterozoic and Neoarchean inherited zircons (1.9 Ga-2.8 Ga), (Table 1a), consistent with a West African craton provenance, which is in agreement with Late Neoproterozoic reconstructions that place the Ossa Morena Zone adjacent to the West African craton (e.g. Murphy et al., 2004 and references therein). The absence of Mesoproterozoic inherited zircons ages (1.7-1.0 Ga) also supports proximity to the West African craton (e.g. Fernández-Suárez et al., 2002; Linnemann et al., 2008).

\subsection{Early Ordovician magmatism}

The Early Ordovician magmatism is represented by the protomylonite trondhjemite and garnet amphibolite both intrusive in the Mouriscas Complex. It occurred in a short period of time between ca. 483 and $477 \mathrm{Ma}$ (Table 1b) and is less important than the Neoproterozoic magmatism that spanned a wider range of time (ca. 692-544 Ma, Tables 1a, b) and space (Fig. 1b). The Early Ordovician rocks have significantly lower $T_{\mathrm{DM}}$ values (0.52 to $0.65 \mathrm{Ga}$ ) and higher $\varepsilon \mathrm{Nd}_{\mathrm{t}}$ values (5.0 to 6.7) than the Neoproterozoic rocks (Tables 2a, b), indicating the input of a juvenile source, including a MORB component $\left(\varepsilon^{2} d_{t}=8.2 ; T_{D M}=0.34 \mathrm{Ga}\right.$, Table 2b). Similar igneous ages are found in the Lower Ophiolite of the Ordenes Complex, NW Iberia (497 \pm 4 Ma; e.g. Arenas et al., 2007), and the Internal Ossa Morena Zone Ophiolite sequences (IOMZOS) (479 \pm 5 Ma; Pedro et al., 2010; Ribeiro et al., 2010a), both considered as remnants of the Rheic Ocean. Lower Ordovician mafic rocks from the Ossa Morena Zone (ca. 471) that are related to intracontinental rifting (Solá 2007; Solá et al., 2008) have lower 
$\varepsilon \mathrm{Nd}_{\mathrm{t}}$ values (1.26 to 3.26). The primitive signature of the Ordovician rocks of this study suggests the existence of mantle melting with possible formation of oceanic crust.

\subsection{Metamorphism}

The metamorphic Precambrian events are well known in the Ossa Morena Zone and has been mentioned since 1878 (e.g. Eguíluz and Ábalos, 1992; Eguíluz et al., 2000; MacPherson, 1878; Quesada, 1997). Intense deformation and poly-metamorphism (Cadomian, Variscan) affected all the rocks within the studied area, except the Carboniferous rhyodacite dykes. Evidence for a major metamorphic event near the Neoproterozoic-early Cambrian boundary (ca. $540 \mathrm{Ma}$ ) is preserved in metamorphic monazite in quartzo-feldspathic schist (540 \pm 3 Ma), (Fig. 4b); Carvalhal orthogneiss (540 \pm 5 Ma), (Fig. 4d); Souto orthogneiss (539 \pm 2 Ma), (Fig. 4g); metamorphic zircon in Cabeço da Moura amphibolite (539 \pm 3 Ma), (Fig. 4i) and metamorphic titanite in Vila Nova amphibolite (529 \pm 5 Ma), (Fig. 4j). P-T thermodynamic modelling for the Sardoal Complex amphibolite $\left(\mathrm{P}=7-8 \mathrm{~kb}, \mathrm{~T}=640-660^{\circ} \mathrm{C}\right)$ (Fig. 7) indicates metamorphism in amphibolite facies conditions, near the transition to the granulite facies. Felsic migmatites in the Sardoal Complex indicate crustal anatexis, generated by high-temperatures. Thermal models for active continental margins indicate that fluids ascending from the subducted oceanic crust are released into the mantle wedge where they lower the solidus and promote partial melting (Wilson, 1989). These data suggest subduction of oceanic crust beneath the Northern margin of Gondwana, followed by continental collision of the Ossa Morena Zone with the Iberian Autochthon passive margin (future Central Iberian Zone) and possibly accretion of an island arc, at ca. 540 Ma.

A second metamorphic event is recognized in Ordovician rocks. According to thermodynamic modelling and mineralogy, they were metamorphosed at amphibolite facies conditions: 
protomylonite trondhjemite $\left(\mathrm{P}=4.5-6.2 \mathrm{~kb}\right.$ and $\left.590-650^{\circ}\right)$ and garnet amphibolite $(6.5 \mathrm{~kb}$ and $550^{\circ} \mathrm{C}$ ) (Henriques et al., 2013). In this study it was not possible to determine the age of the metamorphic event, but it is certainly younger than ca. 477 Ma. The presence of metatexitic and diatexitic structures associated with the garnet amphibolite suggests the existence of a high-temperature metamorphic event.

\section{Summary and conclusions}

The geochronological results are consistent with Neoproterozoic arc magmatism at the Ossa Morena Zone (Figs. 9, 10), generated in different stages of the arc evolution. Island arc magmatism was accompanied by deposition of fine-grained sediments in a Neoproterozoic basin, indicated by the Série Negra succession. The data indicate the existence of an important multistage Cadomian magmatic period at ca. 692 to 544 Ma, in the Ossa Morena Zone (Figs. $9,10)$. The age of $692+77 /-60$ Ma is the oldest documented event of arc magmatism in the Ossa Morena Zone. Another age related to the early arc related magmatism (623 $\pm 3 \mathrm{Ma}$ ) has been published by Sánchez-García et al., 2007. In Cadomia this activity began at ca. 755 Ma (e.g. Nance et al., 2008 and references therein). An early phase of Avalonian arc-related magmatism in Newfoundland (ca. 690-670 Ma; e.g. O’Brien, et al., 1996; Valverde-Vaquero et al., 2006) is coeval with the oldest magmatic event of the Ossa Morena Zone. The igneous crystallization age of the Carvalhal orthogneiss (ca. $569 \mathrm{Ma}$ ) can be correlated with a second major period of intermediate to granitic magmatism in Cadomia (ca. 580-570 Ma; e.g. Inglis et al., 2004). The last episode of Cadomian magmatic activity (ca. 548 Ma and ca. $544 \mathrm{Ma}$ ) involved partial melting of continental crust and mantle and represents the final phase of arc magmatism in the area. The granitoid rocks generated during the Cadomian arc magmatism have lower $\varepsilon \mathrm{Nd}_{\mathrm{t}}$ values than the early rift-related granitoids observed in other areas of the 
Ossa Morena Zone. The development of the Cadomian arc was accompanied by the formation of a back arc basin, where the deposition of the Série Negra occurred (e.g. Linnemann et al., 2008) (Figs. 9, 10). New $P-T$ thermodynamic modelling and U-Pb ages indicate the occurrence of a major medium/high grade metamorphism at ca. $540 \mathrm{Ma}$, interpreted to represent the continental collision of the Ossa Morena Zone with the Iberian Autochthon passive margin (future Central Iberian Zone) and possibly accretion of an island arc. Although, the continental arc accretion has already previously been considered to have occurred close to the Neoproterozoic-Cambrian boundary (e.g. Sánchez-García et al., 2008 and references therein), the new results constrain significantly the timing of the continental arc collision. In the study area, there is no record of the Cambrian rifting that precedes the opening of Rheic Ocean, when the peri-Gondwanan terranes (e.g. Avalonia) drifted from the northern margin of Gondwana (e.g. Murphy et al., 2009). However, rift related magmatic events (bimodal magmatism) were described at Northeast Alentejo in lower Cambrian (e.g. Mata and Munhá, 1990; Ribeiro et al., 1992) and elsewhere in the Ossa Morena Zone (e.g. Sánchez-García et al., 2008; 2010; 2014). The exhumation of relatively deep crustal segments in the study area might prevent the preservation of the volcanic rift related rocks. The Early Ordovician rocks (ca. 483-477 Ma) display field relationships, textures and isotopic compositions different from those of the host rocks and from the chronologically equivalents described in literature and attributed to intracontinental rifting (e.g. Solá et al., 2008). The primitive signature of the Early Ordovician rocks and their juvenile character suggests that they were generated by processes of mantle melting related to the opening of Rheic Ocean (Fig. 10). The latter was consumed in the Carboniferous during the collision between Laurussia and Gondwana that led to the Variscan orogeny (e.g. Murphy et al., 2009). 


\section{Acknowledgments}

627

628

This study was financially supported by a $\mathrm{PhD}$ grant (SFRH/BD/28720/2006) from the Portuguese Foundation for Science given to S.B.A. Henriques. We are grateful to LNEG (Laboratório Nacional de Energia e Geologia, Portugal) where the research was carried out; the Geosciences Centre from Coimbra University, which provided the financial support for the execution of the fieldwork; Ms. Sherri Strong, for technical assistance with U-Pb and tracer Nd and Sr isotopic analyses in the laboratory at Memorial University; Dr. Alain Potrel for assistance with some of the $\mathrm{Nd}$ and $\mathrm{Sr}$ isotopic analyses; Eng. Fernanda Guimarães (LNEG) and Eng. Míguel Fernández González (Oviedo University) for their technical assistance with the microprobe analyses. SBAH is grateful to Jaime Henriques for sample collecting. We are grateful to Dr. Cecilio Quesada, Prof. Fernando Corfu and Dr. Nelson Eby for their careful reviews and constructive suggestions that greatly improve the quality of our manuscript.

\section{References}

Alía, M., 1963. Rasgos estructurales de la baja Extremadura. Boletín Real Sociedad Española Historia Natural (Geología) 20, 247-262.

Arenas, R., Martínez Catalán, J.R., Sánchez Martínez, S., Fernández-Suárez, J., Andonaegui, P., Pearce, J.A., Corfu, F., 2007. The Vila de Cruces Ophiolite: a remnant of the early Rheic Ocean in the Variscan suture of Galicia (northwest Iberian Massif). The Journal of Geology 115, 129-148.

Arndt, N.T., Goldstein, S.L., 1987. Use and abuse of crust-formation ages. Geology 15, 893-895. 
Anderson, D.J., Lindsley, D.H. ,1988. Internally consistent solution models for Fe-Mg-Mn-Ti oxides -

654

Bea, F., Montero, P., Talavera, C., Abu Anbar, M., Scarrow, J.H., Molina, J.F. and Moreno, J.A.,

2010. The paleogeographic position of Central Iberia in Gondwana during the Ordovician: evidence

from zircon chronology and Nd isotopes. Terra Nova 22, 341-346.

658

Lithos 75, 67-87.

662

lead. Analytical Chemistry 41, 525-526.

668

Geosystems 10, Q10014.

Beccaluva, L., Bianchini, G., Bonadiman, C., Siena, F., Vaccaro, C., 2004. Coexisting anorogenic and subduction-related metasomatism in mantle xenoliths from the Betic Cordillera (southern Spain).

Bucher, K., Frey, M., 2002. Petrogenesis of Metamorphic Rocks, seventh ed., Springer, Heidelberg, $341 \mathrm{pp}$.

Cameron, A.E., Smith, D.H., Walker, R.L., 1969. Mass spectrometry of nanogram-size samples of Carvalhosa, A., 1965. Contribuição para o conhecimento geológico da região entre Portel e Ficalho (Alentejo). Memórias dos Serviços Geológicos de Portugal 11, 130 pp.

Conde, L.E.N., 1984. Excursão geológica na região de Ferreira do Zêzêre-Abrantes, in: Museu e Laboratório Mineralógico e Geológico da Universidade de Coimbra (Eds.), Livro-Guia das Excursões da VI Reunião do Grupo Ossa-Morena, 8 pp.

Connolly, J.A.D., 2009. The geodynamic equation of state: what and how. Geochemistry, Geophysics, 
Dale, J., Powell, R., White, R., Elmer, F.L., Holland, T.J.B., 2005. A thermodynamic model for CaNa clinoamphiboles in Na2O-CaO-FeO-MgO- $\mathrm{Al}_{2} \mathrm{O}_{3}-\mathrm{SiO}_{2}-\mathrm{H}_{2} \mathrm{O}-\mathrm{O}$ for petrological calculations. Journal of Metamorphic Geology 23, 771-791.

Davis, D.W., 1982. Optimum linear regression and error estimation applied to U-Pb data. Canadian Journal of Earth Sciences 19, 2142-2149.

DePaolo, D.J., 1981a. A neodymium and strontium isotopic study of the Mesozoic calc-alkaline granitic batholiths of the Sierra Nevada and Peninsular Ranges, California. Journal of Geophysical Research 86, 10470-10488.

DePaolo, D.J., 1981b. Neodymium isotopes in the Colorado front Range and crust-mantle evolution in the Proterozoic. Nature 291, 193-196.

Downes, H., Duthou, J.L., 1988. Isotopic and trace element arguments for the lower-crustal origin of Hercynian granitoids and pre-Hercynian orthogneisses, Massif Central (France). Chemical Geology 68, 291-308.

Eguíluz, L., 1987. Petrogénesis de rocas ígneas y metamórficas en el antiforme de BurguillosMonesterio (Macizo Ibérico Meridional). Ph. D. Thesis, Univ. País Vasco, 456 pp.

Eguíluz, L., Ábalos, B., 1992. Tectonic setting of Cadomian low-pressure metamorphism in the central Ossa-Morena Zone (Iberian Massif, SW Spain). Precambrian Research 56, 113-137.

Eguíluz, L., Ibarguchi, J.I.G., Ábalos, B., Apraiz, A., 2000. Superposed Hercynian and Cadomian orogenic cycles in the Ossa-Morena zone and related areas of the Iberian Massif. Geological Society of America Bulletin 112, 1398-1413. 
Fernández-Suárez, J., Gutiérrez-Alonso, G., Jeffries, T.E., 2002. The importance of along margin terrane transport in northern Gondwana: insights from detrital zircon parentage in Neoproterozoic rocks from Iberia and Brittany. Earth and Planetary Science Letters 204, 75-88.

Gorton, M.P., Schandl, E.S., 2000. From continents to island arcs: a geochemical index of tectonic setting for arc-related and within-plate felsic to intermediate volcanic rocks. The Canadian Mineralogist 38, 1065-1073.

Green E., Holland T., Powell, R., 2007. An order-disorder model for omphacitic pyroxenes in the system jadeite-diopside-hedenbergite-acmite, with applications to eclogitic rocks. American Mineralogist 92, 1181-1189.

Henriques, S.B.A., 2013. Magmatitos e metamorfitos de alto grau no contacto entre as zonas de Ossa Morena e Centro Ibérica: significado geodinâmico. Unpublished $\mathrm{PhD}$ thesis, Universidade de Coimbra, Portugal, 249 pp.

Henriques, S.B.A., Neiva, A.M.R., Ribeiro, M.L., Dunning, G.R., 2010a. Geochemistry and geochronology of a Precambrian active continental margin at the boundary between the Ossa Morena Zone and the Central Iberian Zone, Central Portugal. Goldschmidt Conference Abstracts. Geochimica et Cosmochimica Acta 74, Supplement 1, A400.

Henriques, S.B.A., Neiva, A.M.R., Ribeiro, M.L., Dunning, G.R., 2010b. Island-Arc signature in amphibolites from the boundary between the Ossa Morena Zone and the Central Iberian Zone in Central Portugal. 20th General Meeting of the International Mineralogical Association. Acta Mineralogica-Petrographica Abstract Series 6, 592. World Wide Web Address: http://www.ima2010.hu/img/doc/ima2010_abstracts.pdf. 
Henriques S., Ribeiro M. L., Moreira M. E., 2006. Caracterização petrográfica e geoquímica dos magmatitos da região do Sardoal (Abrantes) e seu enquadramento geodinâmico. Comunicações geológicas INETI 93, 5-21.

Henriques, S.B.A., Ribeiro, M.L., Neiva, A.M.R., Dunning, G.R., Tajcmanova, L., 2013. P-T Evolution of Neoproterozoic and Ordovician Metamorphic Rocks in the Iberian Massif, Central Portugal. Goldschmidt Conference Abstracts. Mineralogical Magazine 77, 1287.

Holland, T.J.B., Powell, R., 1996. Thermodynamics of order-disorder in minerals. 2. Symmetric formalism applied to solid solutions. American Mineralogist 81, 1425-1437.

Holland, T.J.B., Powell, R., 1998. An internally consistent thermodynamic data set for phases of petrological interest. Journal of Metamorphic Geology 16, 309-343.

Hoskin, P.W.O., 2000. Patterns of chaos: fractal statistics and the oscillatory chemistry of zircon. Geochimica et Cosmochimica Acta 64, 1905-1923.

Hoskin, P.W.O., Schaltegger, U., 2003. The composition of zircon and igneous and metamorphic petrogenesis, in: Hanchar, J.M., Hoskin, P.W.O. (Eds.), Zircon. Mineralogical Society of America, Reviews in Mineralogy and Geochemistry 53, pp. 27-62.

Inglis, J.D., Samson, S.D., D’Lemos, R.S., Hamilton, M., 2004. U-Pb geochronological constraints on the tectonothermal evolution of the Paleoproterozoic basement of Cadomia, La Hague, NW France. Precambrian Research 134, 293-315.

Jaffey, A.H., Diamond, H., Bentley,W.C., Flynn, K.F., Rokop, D.J., Essling, A.M., Williams, J., 1977. Half-life of ${ }^{239}$ Pu by two independent methods. Physical Review C 16, 354-369. 
Julivert, M., Fontboté, J.M., Ribeiro, A., Conde, L., 1972. Mapa tectónico de la Península Ibérica y Baleares, E: 1:1,000,000. Instituto Geológico y Minero de España, Madrid.

Krogh, T.E., 1973. A low contamination method hydrothermal decomposition of zircon and extraction of $\mathrm{U}$ and $\mathrm{Pb}$ for isotopic age determinations. Geochimica et Cosmochimica Acta 37, 485-494.

Krogh, T.E., 1982. Improved accuracy of U-Pb zircon ages by the creation of more concordant systems using an air abrasion technique. Geochimica et Cosmochimica Acta 46, 637-649.

Linnemann, U., McNaughton, N.J., Romer, R.L., Gehmlich, M., Drost, K., Tonk, Ch., 2004. West African provenance for Saxo-Thuringia (Bohemian Massif): Did Armorica ever leave pre-Pangean Gondwana? U/Pb-SHRIMP zircon evidence and the Nd-isotopic record. International Journal of Earth Sciences 93, 683-705.

Linnemann, U., Pereira, M.F., Jeffries ,T.E., Drost, K., Gerdes, A., 2008. The Cadomian Orogeny and the opening of the Rheic Ocean: The diachrony of geotectonic processes constrained by LA-ICP-MS $\mathrm{U}-\mathrm{Pb}$ zircon dating (Ossa-Morena and Saxo-Thuringian Zones, Iberian and Bohemian Massifs). Tectonophysics 461, 21-43.

López-Guijarro, R., Armendáriz, M., Quesada, C., Fernández-Suárez, J., Murphy, J.B, Pin, C., Bellido, F., 2008. Ediacaran-Palaeozoic tectonic evolution of the Ossa Morena and Central Iberian zones (SW Iberia) as revealed by Sm-Nd isotope systematics. Tectonophysics 461, 202-214.

Lotze, F., 1945. Zur Gliederung der Varisciden der Iberishen Mesetas. Geoteckt Forsch 6, 78-92. Traducción española por Ríos, J.M. 1950. Observaciones respecto a la división de las Varíscides de la Meseta Ibérica. Publicaciones extranjeras sobre geología de España 5, 149-166. 
Ludwig, K.R. 2003. ISOPLOT 3.00: A geochronological Toolkit for Microsoft Excel. Berkeley Geochronology Center Special Publication 4, 70 pp.

MacPherson, J., 1878. Sobre la existencia de la fauna primordial en la provincia de Sevilla. Anales de la Sociedad Española de Historia Natural 7, 281-284.

Manhés, G., Minster, J.F., Allégre, C.J., 1978. Comparative U-Th-Pb and Rb-Sr study of the Saint Séverin amphoterite: consequence for early solar system chronology. Earth and Planetary Science Letters 39, 14-24.

Mata, J., Munhá, J., 1990. Magmatogénese de metavulcanitos câmbricos do Nordeste Alentejano: os estádios iniciais de rifting continental. Comunicações dos Serviços Geológicos de Portugal 76, 61-89.

Mattinson, J.M., 2005. Zircon U-Pb chemical-abrasion (CA-TIMS) method: combined annealing and multi-step dissolution analysis for improved precision and accuracy of zircon ages. Chemical Geology 220, 47-66.

McCann, T., 2008. Introduction and overview, in: McCann, T. (Ed.), The Geology of central Europe: Precambrian and Paleozoic. Geological Society, London, pp. 1-20.

Murphy, J.B., Nance, R.D., 2002. Sm-Nd isotopic systematics as tectonic tracers: an example from West Avalonia in the Canadian Appalachians. Earth-Science Reviews 59, 77-100.

Murphy, J.B., Pisarevsky, S.A., Nance, R.D., Keppie, J.D., 2004. Neoproterozoic-Early Paleozoic evolution of peri-Gondwanan terranes: implications for Laurentia-Gondwana connections. International Journal of Earth Sciences 93, 659-682. 
Murphy, J.B., Gutiérrez-Alonso, G., Nance, R.D., Fernández-Suárez, J., Keppie, J.D., Quesada, C., Strachan, R.A., Dostal, J., 2006. Origin of the Rheic Ocean: Rifting along a Neoproterozoic suture? Geology 34, 325-328.

Murphy, J.B., Gutiérrez-Alonso, G., Nance, R.D., Fernández-Suárez, J., Keppie, J.D., Quesada C., Dostal, J.A., Braid, J., 2009. Rheic Ocean mafic complexes: overview and synthesis, in: Murphy J.B., Keppie, J.D., Hynes, A.J. (Eds.), Ancient Orogens and Modern Analogues. Geological Society, London, Special Publications 327, pp. 343-369.

Nance, R.D., Murphy, J.B., Strachan, R.A., Keppie, J.D., Gutiérrez-Alonso, G., Fernández-Suárez, J., Quesada, C., Linnemann, U., D’Lemos, R., Pisarevsky, S.A., 2008. Neoproterozoic-early Palaeozoic tectonostratigraphy and palaeogeography of the peri-Gondwanan terranes Amazonian v. West African connections, in: Ennih N., Liégeois J.P. (Eds.), The Boundaries of the West African Craton. Geological Society, London, Special Publications 297, pp. 345-383.

Newton, R.C., Charlu, T.V., Kleppa, O.J., 1980. Thermochemistry of the high structural state plagioclases. Geochimica Cosmochimica Acta 44, 933-941.

O’Brien, S.J., O’Brien, B.H., Dunning, G.R., Tucker, R.D., 1996. Late Neoproterozoic Avalonian and related peri-Gondwanan rocks of the Newfoundland Appalachians, in: Nance, R.D., Thompson, M.A., (Eds.), Avalonian and Related Peri-Gondwanan Terranes of the Circum-North Atlantic. Geological Society of America, Special Papers, 304, pp. 9-28.

Parrish, R., 1990. U-Pb dating of monazite and its application to geological problems. Canadian Journal of Earth Sciences 17, 1431-1450.

Parrish, R.R., Krogh, T.E., 1987. Synthesis and purification of ${ }^{205} \mathrm{~Pb}$ for U-Pb for geochronology. Chemical Geology 66, 103-110. 
Pearce, J.A., 1983. Role of the sub-continental lithosphere in magma genesis at active continental

846

847

848

849

850

851

852

853

854

855

856

857

858

859

860

861

862

863

864

865

866

867

868

869

870

margins, in: Hawkesworh, C.J., Norry, M.J., (Eds.), Continental basalts and mantle xenoliths, Shiva,

Nantwich, Cheshire, U.K., pp. 230-249.

Pedro, J.C., Araújo, A., Fonseca, P.E., Tassinari, C., Ribeiro, A., 2010. Geochemistry and U-Pb zircon age of the Internal Ossa-Morena Zone Ophiolite Sequences: a remnant of Rheic Ocean in SW Iberia. Ofioliti 35(2), 117-130.

Pereira, M.F., Chichorro, M., Linnemann, U., Eguíluz, L., Silva, J.B., 2006. Inherited arc signature in Ediacaran and Early Cambrian basins of the Ossa-Morena Zone (Iberian Massif, Portugal): paleogeographic link with European and North African Cadomian correlatives. Precambrian Research 144, 297-315.

Pereira, E., Romão, J., Conde, L., 1998. Geologia da Transversal de Tomar-Mação Sutura entre a Zona Centro Ibérica (ZCI) e a Zona de Ossa-Morena (ZOM), in: Oliveira, J.T., Pereira, R., (Eds.), Livro guia das excursões do V Congresso Nacional de Geologia. Instituto Geológico e Mineiro, pp. 159-188.

Quesada. C., Munhá, J., 1990. Metamorphism in the Ossa-Morena Zone, in: Dallmeyer, R.D., Martínez-García, E. (Eds.), Pre-Mesozoic Geology of Iberia. Springer-Verlag, Heidelberg, pp. 314320.

Quesada, C., 1990a. Precambrian terranes in the Iberian Variscan foldbelt, in: Strachan, R.A., Taylor, G.K. (Eds.), Avalonian and Cadomian Geology of the North Atlantic. Blackie and Sons, Oxford, pp. 109-133. 
Quesada, C., 1990b. Precambrian successions in SW Iberia: their relationships to Cadomian orogenic events, in: D'Lemos, R.S., Strachan, R.A., Topley, C.G. (Eds.), The Cadomian Orogeny. Geological Society of London, Special Publication 51, pp. 353-362.

Quesada, C., 1997. Evolución geodinámica de la Zona Ossa Morena durante el ciclo Cadomiense.,in: Araújo, A.A., Pereira, M.F. (Eds.), Estudo sobre a geología da zona de Ossa Morena (Maciço Ibérico). Livro homenagem Prof. Francisco Gonçalves, University of Évora, pp. 205-230.

Quesada, C., 2006. The Ossa Morena Zone of the Iberian Massif: a tectonostratigraphic approach to its evolution. Zeitschrift der Deutschen Gesellschaft für Geowissenschaften 157(4), 585-595.

Ribeiro, A., Quesada, C., Dallmeyer, R.D., 1990. Geodynamic evolution of the Iberian Massif, in: Dallmeyer R.D., Martínez-García E. (Eds.), Pre-Mesozoic Geology of Iberia. Springer-Verlag, Heidelberg, pp. 397-410.

Ribeiro, A., Munhá, J., Mateus, A., Fonseca, P. E., Noronha, F., Romão, J., Rodrigues, J., Castro, P., Meireles, C., Ferreira, N., 2009. Mechanics of thick-skinned Variscan overprinting of Cadomian basement (Iberian Variscides). Comptes Rendus Geoscience 341, 127-139.

Ribeiro, A., Munhá, J., Fonseca, P.E., Araújo, A., Pedro, J.C., Mateus, A., Tassinari, C., Machado, G., Jesus, A., 2010a. Variscan ophiolite belts in the Ossa-Morena Zone (Southwest Iberia): geological characterization and geodynamic significance. Gondwana Research 17, 408-421.

Ribeiro A., Romão, J., Henriques, S., Dunning, G., Ribeiro, L., Neiva A., Munhá, J., Pereira, E., Castro, P., 2010b. Thick-skinned inter-plate and intra-plate tectonics in NW and SW Iberia. VIII Congresso Nacional de Geologia. e-Terra 11. World Wide Web Address: http://metododirecto.pt/CNG2010/index.php/vol/article/view/194/232. 
Ribeiro, A., 2013. Evolução geodinâmica de Portugal; os ciclos ante-mesozóicos, in: Dias R., Araújo, A., Terrinha, P., Kullberg, J. (Eds.), Geologia de Portugal, Vol. I. Escolar Editora, pp. 15-57.

Ribeiro, A., Romão, J., Munhá, J., Rodrigues, J. F., Pereira, E., Mateus, A., Araújo, A., Dias, R., 2013. Relações tectono-estratigráficas e fronteiras entre as Zonas Centro-Ibérica e Ossa-Morena do Terreno Ibérico e o Terreno Finisterra, in: Dias R., Araújo A., Terrinha P., Kullberg, J. (Eds.), Geologia de Portugal, Vol. I. Escolar Editora, pp. 439-481.

Ribeiro, M.L., Mata, J., Piçarra, J.M., 1992. Vulcanismo bimodal da região de Ficalho: características geoquímicas. Comunicações dos Serviços Geológicos de Portugal 78(2), 75-85.

Ribeiro, M. L., Palácios, T., Munhá, J., 1995. Aspectos petrológicos-geoquímicos do Complexo eruptivo de Mouríscas (Abrantes). Resumo alargado, IV Congressso Nacional de Geologia. Memórias do Museu do Laboratório Mineralógico e Geológico da Faculdade de Ciências da Universidade do Porto 4, 805-807.

Ribeiro, M. L., Pereira, F., Solá, A. R., 2003. O ciclo cadominano na ZOM: evidências geoquímicas. Resumo: IV Congresso Ibérico de Geoquímica, XIII Semana de Geoquímica, Coimbra, 69-71.

Rollinson, H.R., 1993. Using geochemical data: evaluation, presentation, interpretation. Longman, Harlow, 352 pp.

Romão, J., Esperancinha, A., 2000. Carta Geológica de Portugal, escala 1: 50 000, Folha 28-A (Mação). Instituto Geológico e Mineiro, Portugal.

Romão, J., 2006. Notícia explicativa da Carta Geológica de Portugal à escala 1: 50 000, Folha 28-A (Mação), Instituto Nacional de Engenharia Tecnologia e Inovação, Portugal, 77 pp. 
Sánchez-García, T., Quesada, C., Dunning, G.R., Perejón, A., Bellido, F., Moreno-Eiris, E., 2007. New geochronological and geochemical data of the Loma del Aire Unit, Ossa- Morena Zone. IGCP 497-Galicia Meeting 2007. Publicaciones del IGME, pp. 164-165.

Sánchez-García, T., Quesada, C., Bellido, F., Dunning, G.R., González del Tánago, J., 2008. Two-step magma flooding of the upper crust during rifting: the Early Paleozoic of the Ossa Morena Zone (SW Iberia). Tectonophysics 461, 72-90.

Sánchez-García, T., Bellido, F., Pereira, M.F., Chichorro, M., Quesada, C., Pin, Ch. \& Silva, J.B. 2010. Rift-related volcanism predating the birth of the Rheic Ocean (Ossa-Morena zone, SW Iberia). Gondwana Research 17, 392-407.

Sánchez-García, T., Pereira, M.F., Bellido, F., Chichorro, M., Silva, J.B., Valverde-Vaquero, P., Pin, Ch., Solá, A.R., 2014. Early Cambrian granitoids of North Gondwana margin in the transition from a convergent setting to intra-continental rifting (Ossa-Morena Zone, SW Iberia). International Journal of Earth Sciences 103, 1203-1218.

Samson, S.D., D’Lemos, R.S., Blichert-Toft, J., Vervoort, J., 2003. U-Pb geochronology and Hf-Nd isotope compositions of the oldest Neoproterozoic crust within the Cadomian orogen: New evidence for a unique juvenile terrane. Earth and Planetary Science Letters 208, 165-180.

Schärer, U., 1984. The effect of initial ${ }^{230}$ Th disequilibrium on young U-Pb ages: the Makalu case, Himalaya. Earth and Planetary Science Letters 67, 191-204.

Siivola, J., Schmid, R., 2007. List of mineral abbreviations, in: Fettes, D., Desmons, J. (Eds.), Metamorphic Rocks: A classification and Glossary of Terms, Recommendations of the International Union of Geological Sciences, Subcommission on the Systematics of Metamorphic Rocks. Cambridge University Press, New York, pp. 93-110. 
Solá, A.R., 2007. Relações Petrogeoquímicas dos Maciços Graníticos do NE Alentejano. Unpublished

PhD thesis, University of Coimbra, Portugal, 405 pp.

958

Solá, A. R., Pereira, M. F., Ribeiro, M. L., Neiva, A. M. R., Williams, I. S., Montero, P., Bea, F.,

Zinger, T., 2008. New insights from zircon ages on the Lower Ordovician magmatism of the northern

Gondwana margin: the Urra Formation (SW Iberian Massif, Portugal). Tectonophysics 461, 114-129.

Stacey, J.S., Kramers, J.D., 1975. Approximation of terrestrial lead isotope evolution by a two-stage model. Earth and Planetary Science Letters 34, 207-226.

965 reconstructions. Contributions to Mineralogy and Petrology 118, 13-32.

Steiger, R.H., Jäger, E., 1977. Subcomission on geochronology: convention on the use of decay constants in geo-and cosmochronology. Earth and Planetary Science Letters 36, 359-362.

Tanaka, T., Togashi, S., Kamioka, H., Amakawa, H., Kagami, H., Hamamoto, T., Yuhara, M., Orihashi, T., Yoneda, S., Shimizu, H., Kunimaru, T., Takahashi, K., Yanagi, T., Nakano, T., Fujimaki, H., Shinjo, R., Asahara, Y., Tanimizu, M., Dragusanu, C., 2000. JNdi-1: a neodymium isotopic reference in consistency with LaJolla neodymium. Chemical Geology 168, 279-81.

Teixeira, C., 1981. Geologia de Portugal: Precâmbrico-Paleozóico. Fundação Calouste Gulbenkian, Lisboa, 630 pp.

Turpin, L., Cuney, M., Friedrich, M., Bouchez, J.L., Aubertin, M., 1990. Meta-igneous origin of Hercynian peraluminous granites in the NW French Massif Central: implications for crustal history 
Valverde-Vaquero, P., Dunning, G.R., O’Brien, S.J., 2006. Polycyclic evolution of the Late Neoproterozoic basement in the Hermitage Flexure region (southwest Newfoundland Appalachians): New evidence from the Cinq-Cerf gneiss. Precambrian Research 148, 1-18.

Villaseca, C., Barbero, L., Rogers, G., 1998. Crystal origin of Hercynian peraluminous granitic batholits of Central Spain: petrological, geochemical and isotopic (Sr, Nd) constraints. Lithos 43, 5579.

Villaseca, C., Orejana, D., Pin, C., López García, J.A., Andonaegui, P., 2004. Le magmatisme basique hercynien et post-hercynien du Système Central Espagnol: essai de caractérisation des sources mantelliques. Comptes Rendus Géosciences 336, 877-888.

Villaseca, C., Belousova, E., Orejana, D., Castiñeiras, P., Pérez-Soba, C., 2011. Presence of Palaeoproterozoic and Archean components in the granulite-facies rocks of central Iberia: The Hf isotopic evidence. Precambrian Research 187, 143-154.

Wilson, M., 1989. Igneous Petrogenesis. Unwin Hyman, London, 466 pp.

Wood, D.A., 1980. The application of a Th-Hf-Ta diagram to problems of tectonomagmatic classification and to establishing the nature of crustal contamination of basaltic lavas of the British Tertiary volcanic province. Earth and Planetary Science Letters 50, 11-30.

Zbyszewski, G., Ribeiro, O., Gonçalves, F., Carvalhosa, A., 1983. Carta Geológica de Portugal, escala 1: 50 000, Folha 28-C (Gavião), Serviços Geológicos de Portugal. Serviços Geológicos de Portugal.

Zbyszewski, G., Carvalhosa, A., Gonçalves, F., 1981. Notícia explicativa da Carta geológica de Portugal à escala 1: 50 000, Folha 28-C (Gavião). Serviços Geológicos de Portugal, 50 pp. 
1 Fig. 1. (a) Subdivision of the Iberian Massif after Ribeiro (2013) and location of the studied

2 area. (b) Geological map adapted from Zbyszewski et al. (1983), Conde (1984) and Romão and

3 Esperancinha (2000). Thrust faults after Ribeiro et al. (2013). Projection system:

4 ETRS_1989_Portugal_TM06. (c) SW-NE general cross section of Alvrangel - Olalhas area

5 after Conde (1984).

6 Fig. 2. Field and petrographic features of the studied rocks. (a) Porphyroclastic texture,

7 mylonitic fabric and ribbon quartz, observed in orthogneiss (Sardoal Complex). (b) Banded

8 structure of Carvalhal orthogneiss (Sardoal Complex). (c) Stromatic migmatite (Sardoal

9 Complex). (d) Muscovite overgrowing sillimanite, observed in Sardoal orthogneiss (Sardoal

10 Complex). (e) Relict staurolite inclusion in muscovite, observed in Olalhas orthogneiss

11 (Sardoal Complex). (f) Granofelsic texture of Mouriscas Complex amphibolite. (g)

12 Porphyroclastic texture and mylonitic fabric observed in amphibolite (Mouriscas Complex). (h)

13 Garnet amphibolite large garnet grains surrounded by light-colored halos (Mouriscas

14 Complex). (Mg-Hbl-Magnesium hornblende; Ms-muscovite; Qtz-quartz; Sil-sillimanite; St-

15 staurolite; Pl-plagioclase).

16 Fig. 3. Zircon cathodo-luminescence images of the studied samples.

17 Fig. 4. U-Pb Concordia diagram for samples from Sardoal Complex. Error ellipses are plotted 18 with $2 \sigma$ uncertainties. M-monazite, T-titanite, Z-zircon.

19 Fig. 5. U-Pb Concordia diagram for samples from Mouriscas Complex. Error ellipses are 20 plotted with $2 \sigma$ uncertainties. M-monazite, Z-zircon.

21 Fig. 6. $\varepsilon \mathrm{Nd}_{\mathrm{t}}$ vs. $\left({ }^{87} \mathrm{Sr} /{ }^{86} \mathrm{Sr}\right)_{\mathrm{i}}$ plot for the studied samples. Fields for MORB from Wilson (1989), 22 lithospheric mantle from Beccaluva et al. (2004) in Villaseca et al. (2004), mantle array from 23 Rollinson (1993), for meta-igneous and metasedimentary middle-upper crust and 24 metasedimentary lower crust from Turpin et al. (1990), Downes and Duthou (1988) in 25 Villaseca et al. (1998). The fields were corrected for the Early Palaeozoic. 
Fig. 7. (a, b) P-T diagram for sample 311-1, Cabeço da Moura amphibolite (Sardoal Complex), calculated in NCFMASHTO system. The ellipse represents the estimated $P$ - $T$ conditions in the observed stability field.

Fig. 8. $\varepsilon \mathrm{Nd}_{\mathrm{t}}$ vs. time $(\mathrm{Ga})$ diagram for the Neoproterozoic rocks in this study (after Murphy et al. 2006; Murphy and Nance 2002). Sm-Nd isotopic data for Armorican rocks are from Samson et al. (2003); Avalonian and Cadomian rocks from Murphy and Nance (2002 and references therein); Saxo-Thuringian rocks (Bohemian Massif) from Linnemann et al. (2004). Depleted mantle curve is from DePaolo (1981b). CHUR: chondrite uniform reservoir.

Fig. 9. Global paleocontinental reconstruction from the Late Neoproterozoic and schematic representation of the island-arc, Ossa Morena Zone (OMZ) and other Cadomian-type terranes: Armorican Massif (AM) and Saxo-Thuringian Zone (SXZ). Modified from Linnemann et al. (2008), McCann 2008 and Nance et al. 2008.

Fig. 10. Schematic representation of the main magmatic and tectonometamorphic events. Cross-sections of island-arc (I) and active continental margin (II) are based on cross-sections 40 from Wilson (1989). OMZ-Ossa Morena Zone; CIZ-central Iberian Zone. 

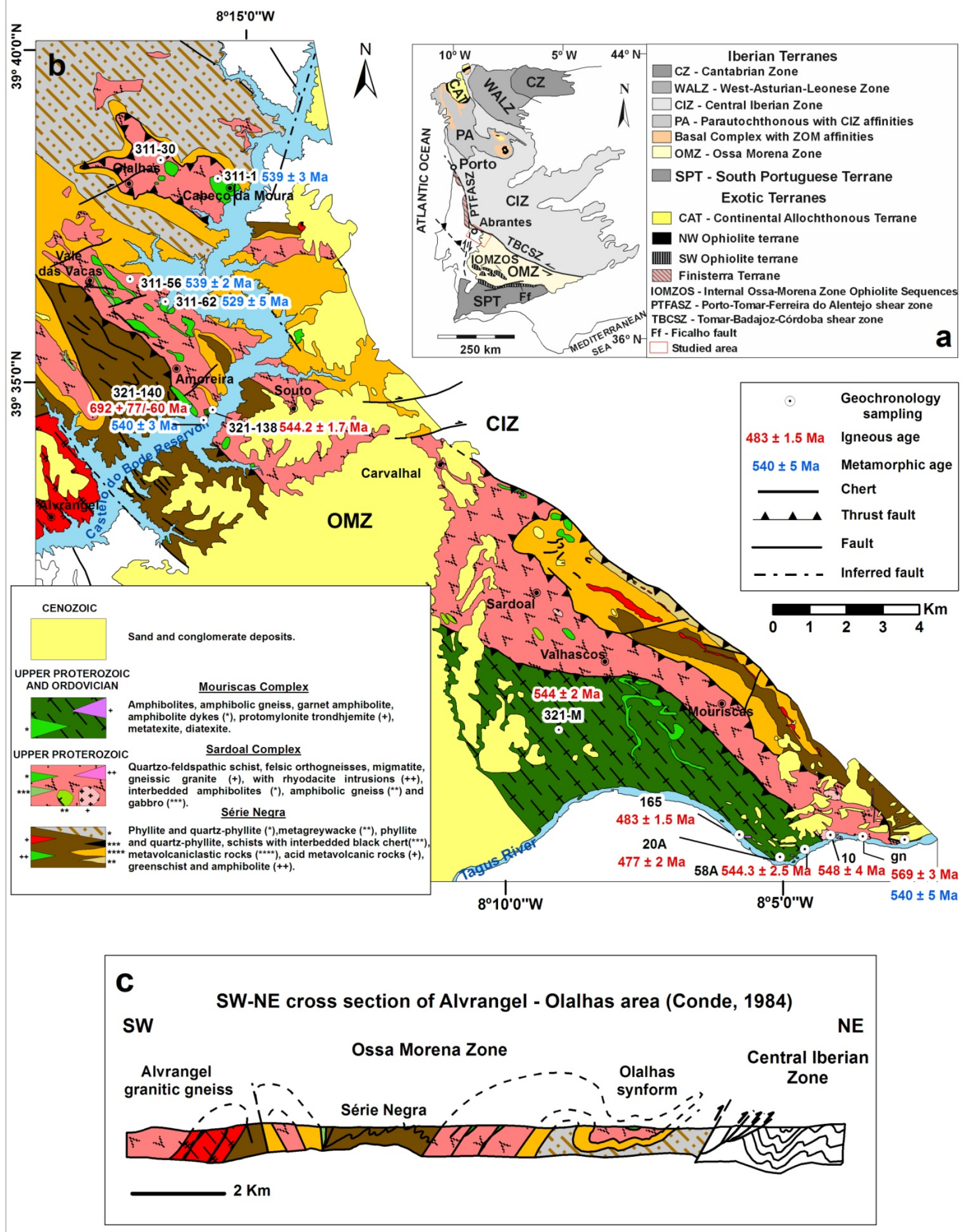

Fig. 1 

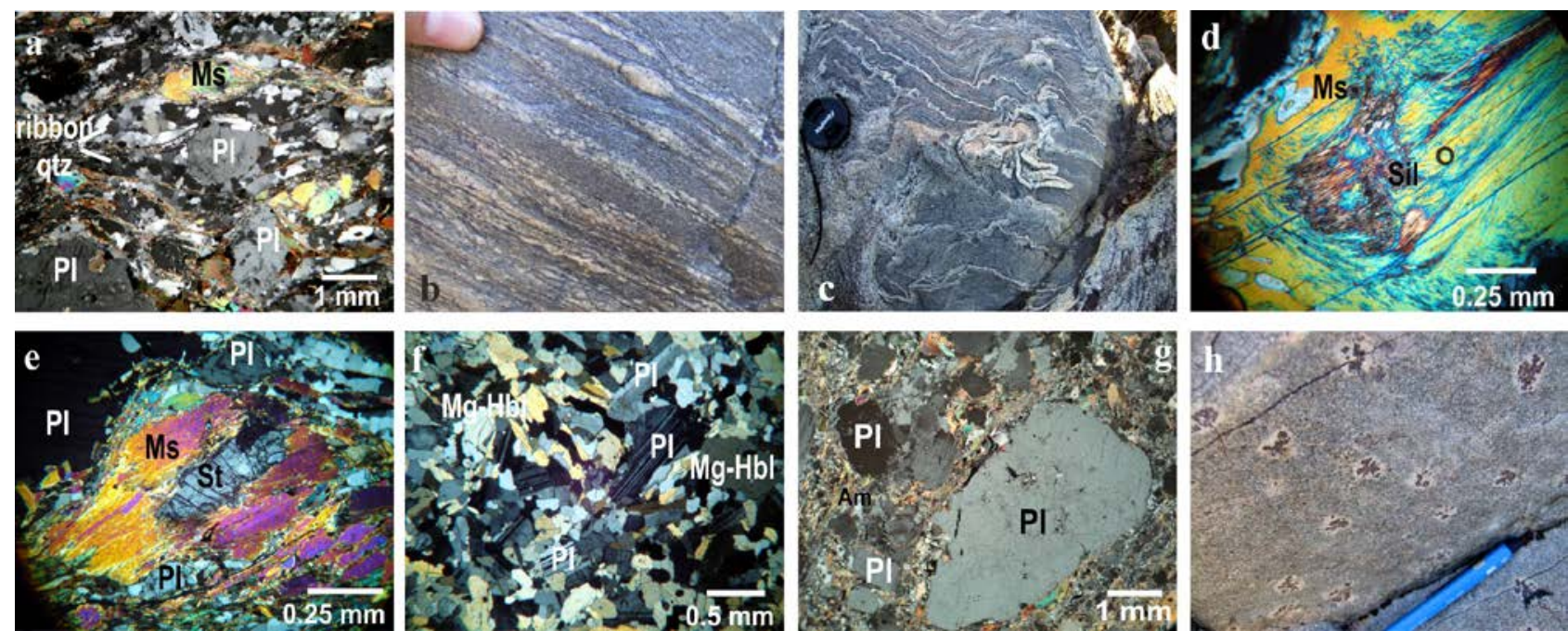

Fig. 2 
Sardoal Complex:

quartzo-feldspathic schist (321-140)

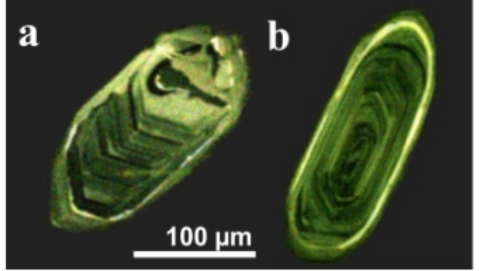

Sardoal Complex:

Souto orthogneiss (311-56)

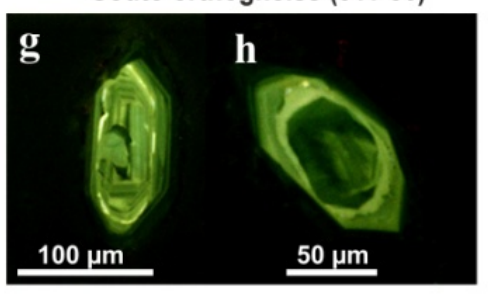

Mouriscas Complex: amphibolites

$321-138$

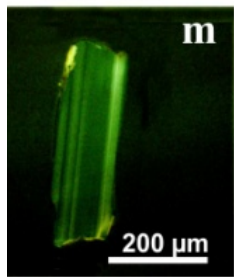

$58 \mathrm{~A}$

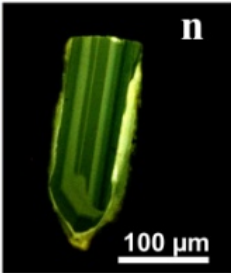

Sardoal Complex: Carvalhal orthogneiss (gn)

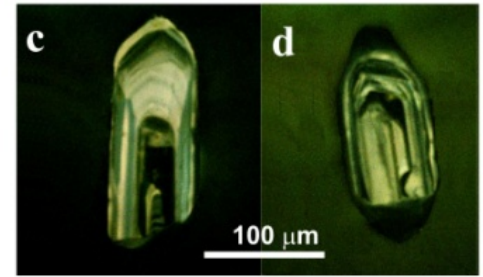

Sardoal Complex:

Olalhas orthogneiss (311-30)

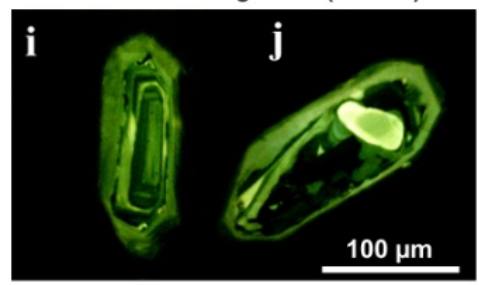

Sardoal Complex:

Sardoal orthogneiss (10)

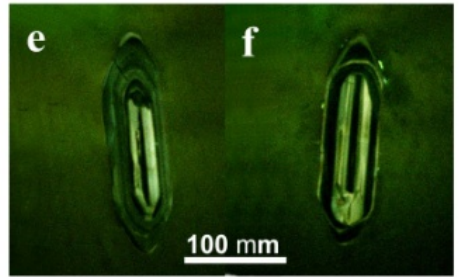

Sardoal Complex:

Cabeço da Moura amphibolite (311-1)

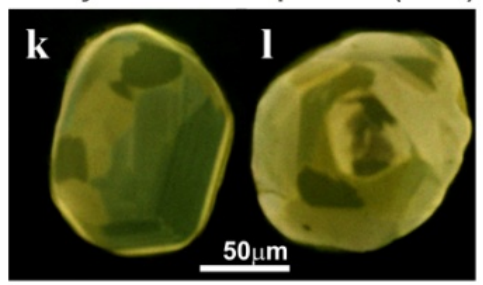

Mouriscas Complex:

Mouriscas Complex:

321-M protomylonite trondhjemite (165) garnet amphibolite (20A)
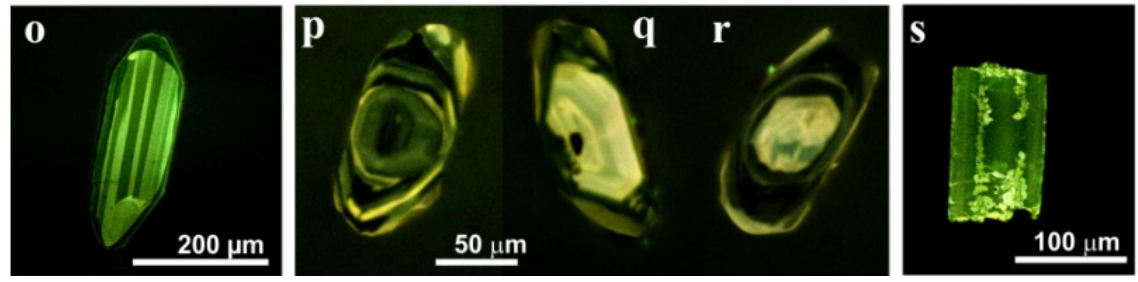

Fig. 3 

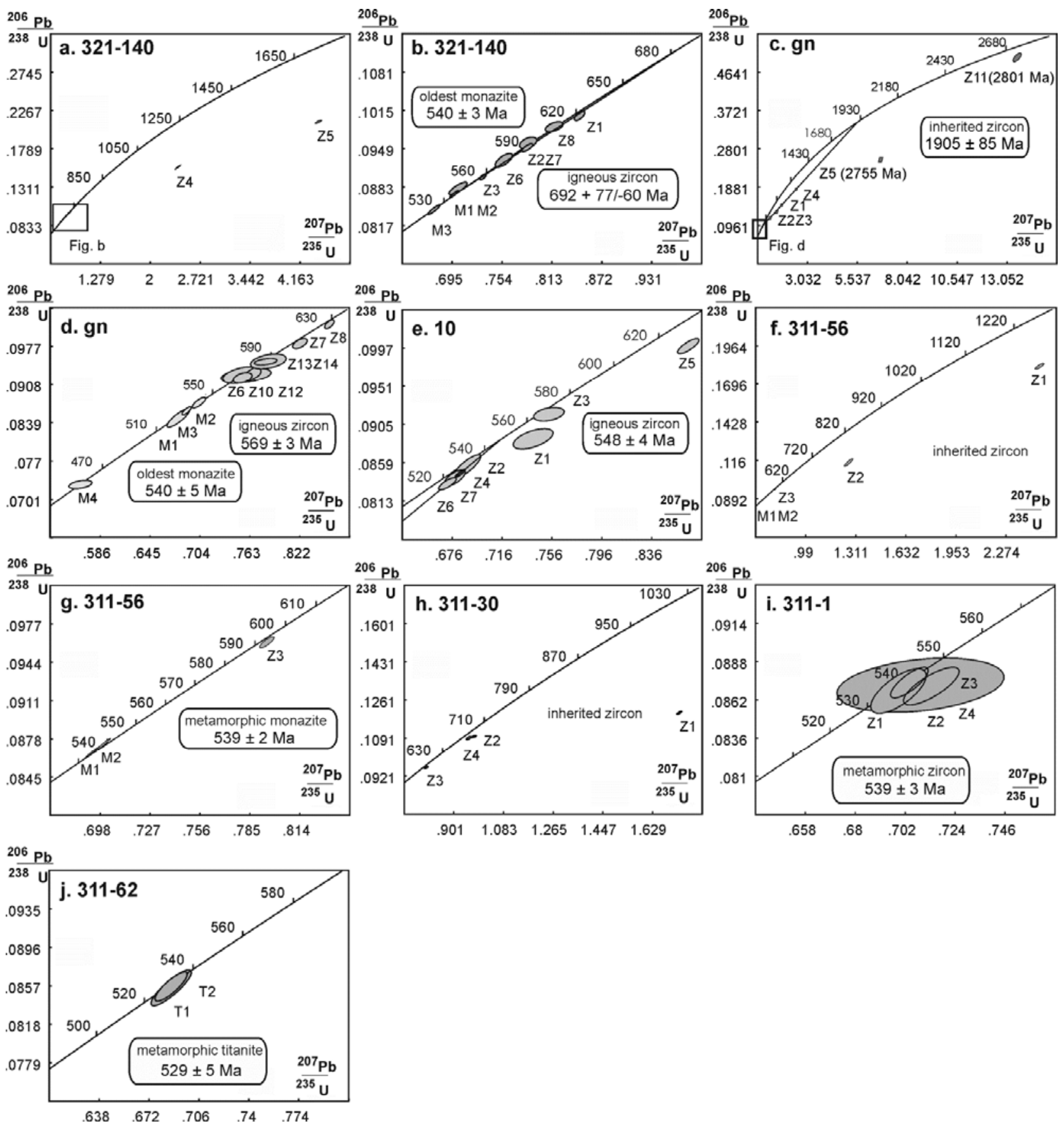

Fig. 4 


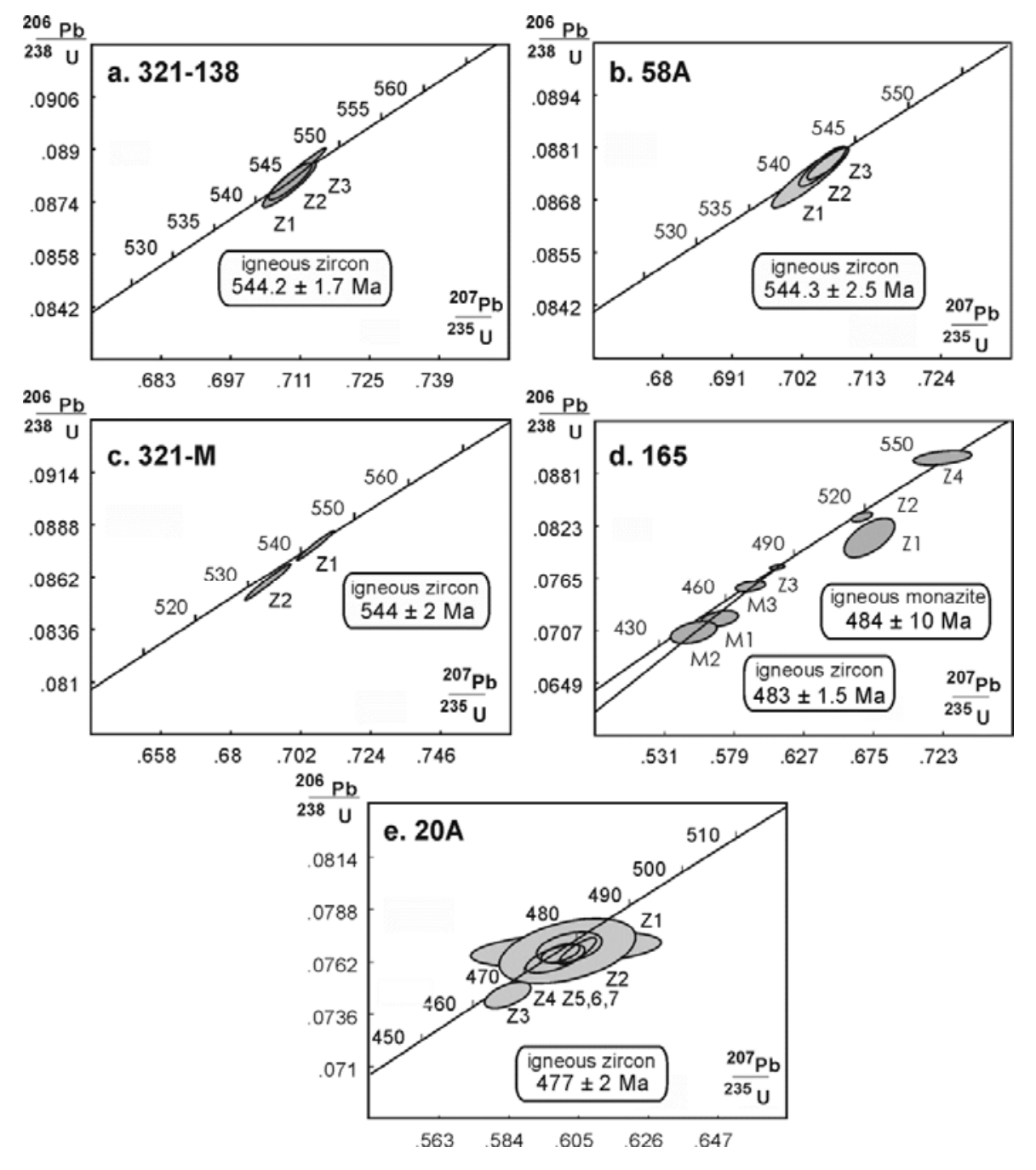

Fig. 5 


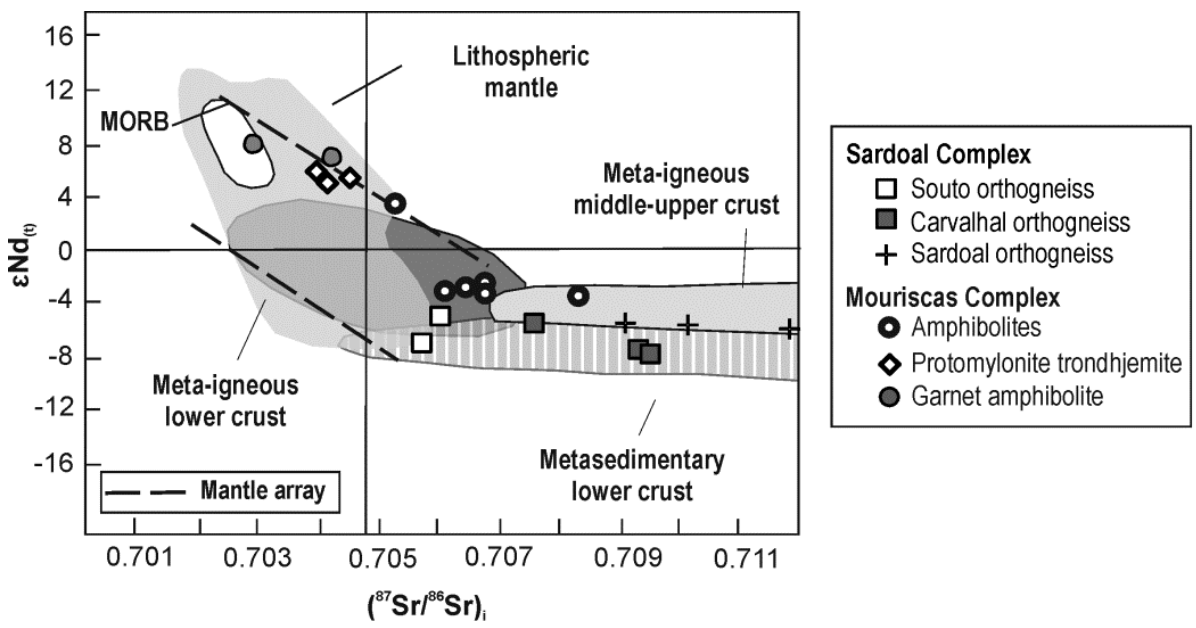

Fig. 6 

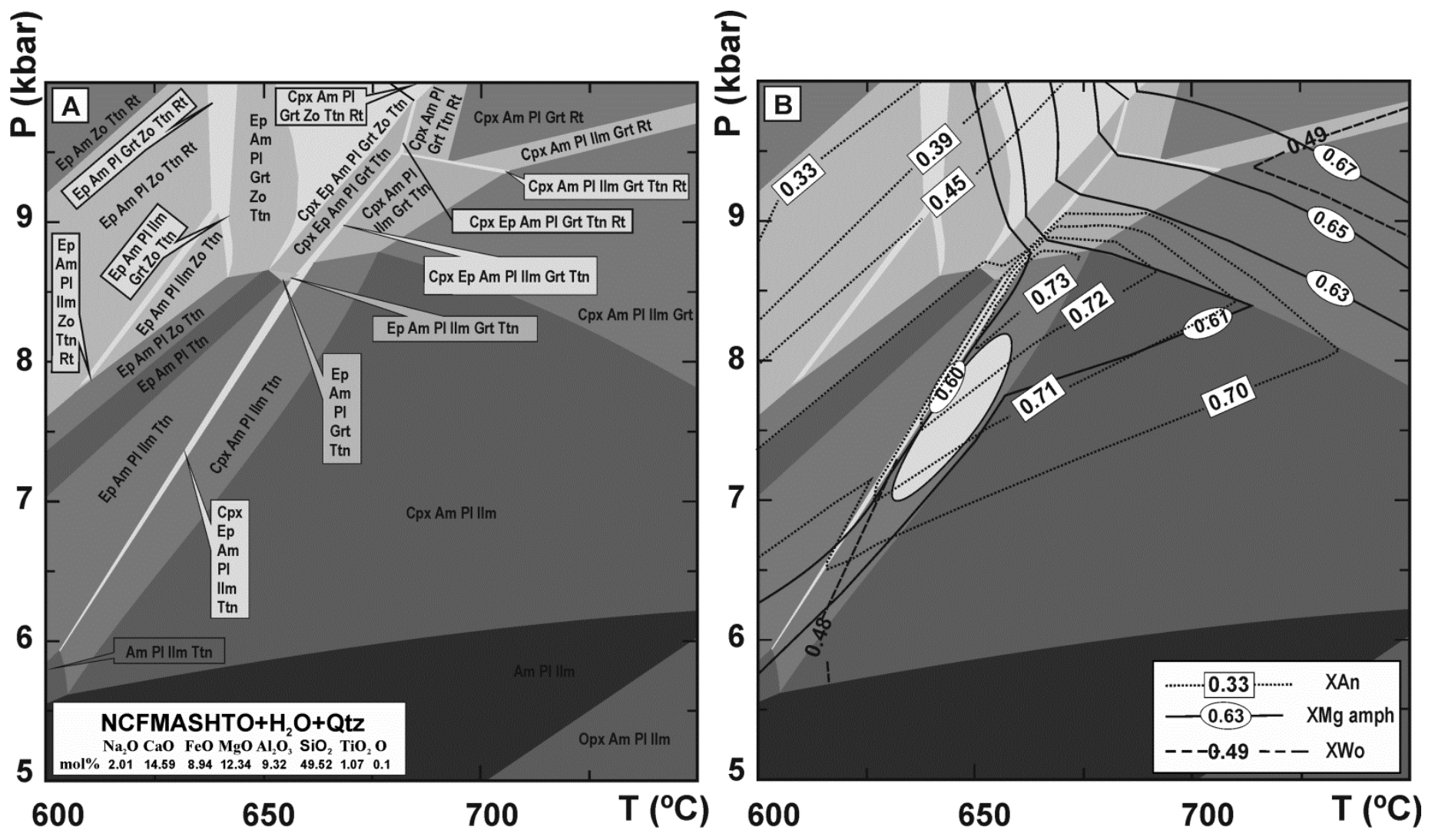

Fig. 7 


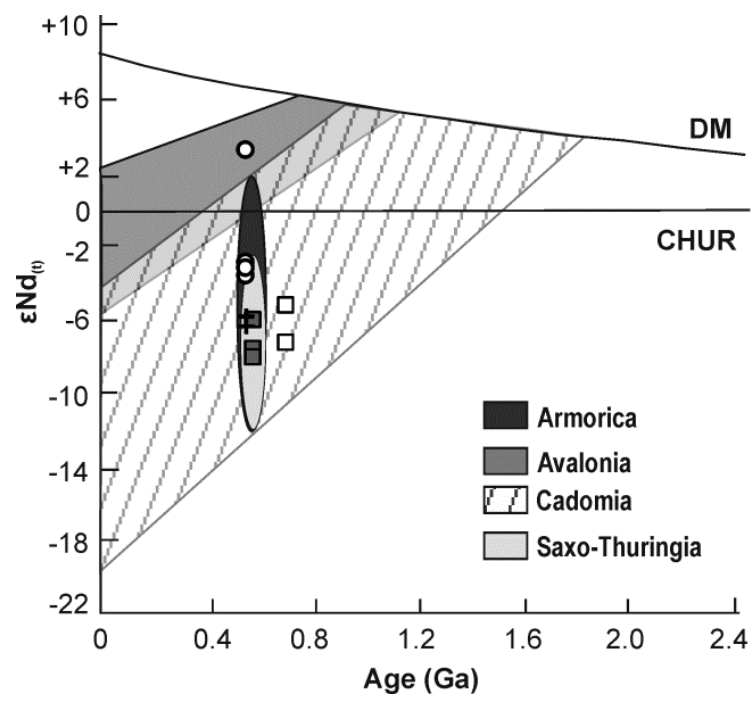

Sardoal Complex

$\square$ Souto orthogneiss

$\square$ Carvalhal orthogneiss

+ Sardoal orthogneiss

Mouriscas Complex

- Amphibolites

Fig. 8 


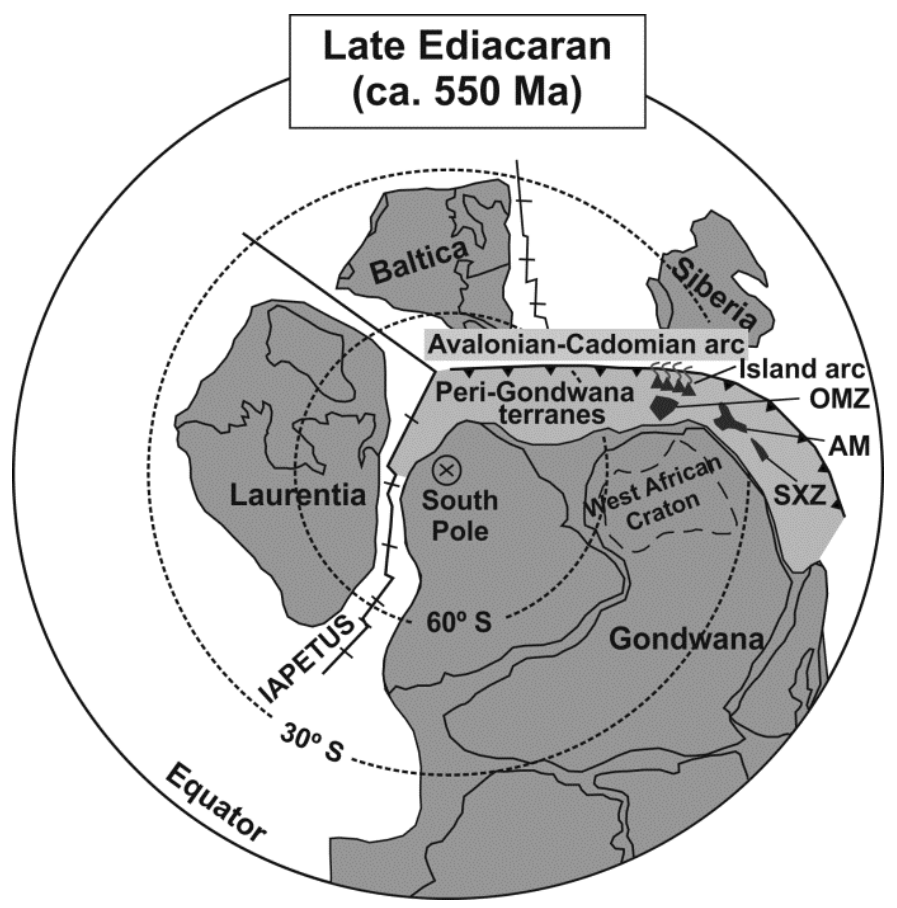

Fig. 9 
I) Deposition of fine-grained sediments on a Neoproterozoic basin with evidence of an island arc, Cryogenian? - Ediacaran.

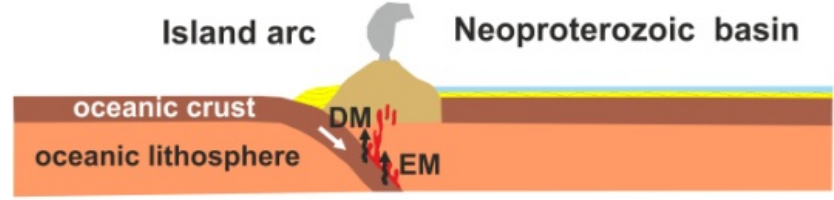

DM - Depleted mantle EM - Enriched mantle $\checkmark$ partial melting $\uparrow \mathrm{H}_{2} \mathrm{O} \square$ sediments

II) Development of the Cadomian arc with formation of a back-arc basin (ca. 692 - 544 Ma; Cryogenian - Ediacaran).

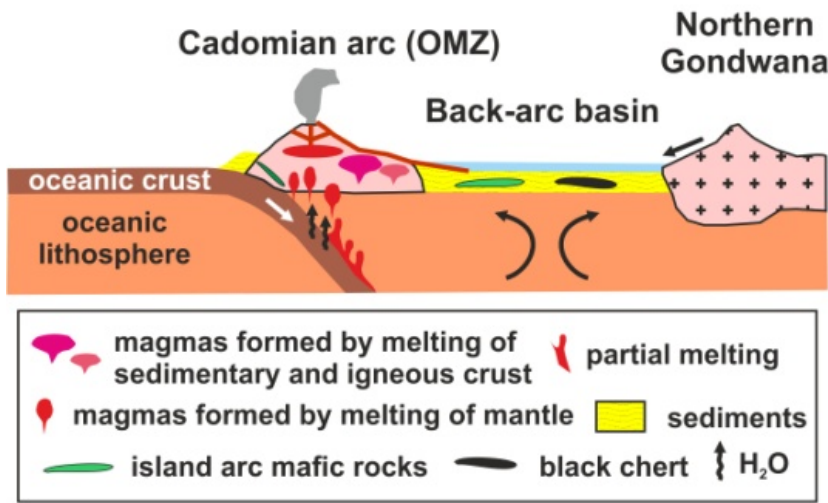

III) Continental collision of the Ossa Morena Zone (OMZ) with the Iberian autochthon (ca. $540 \mathrm{Ma}$ ).

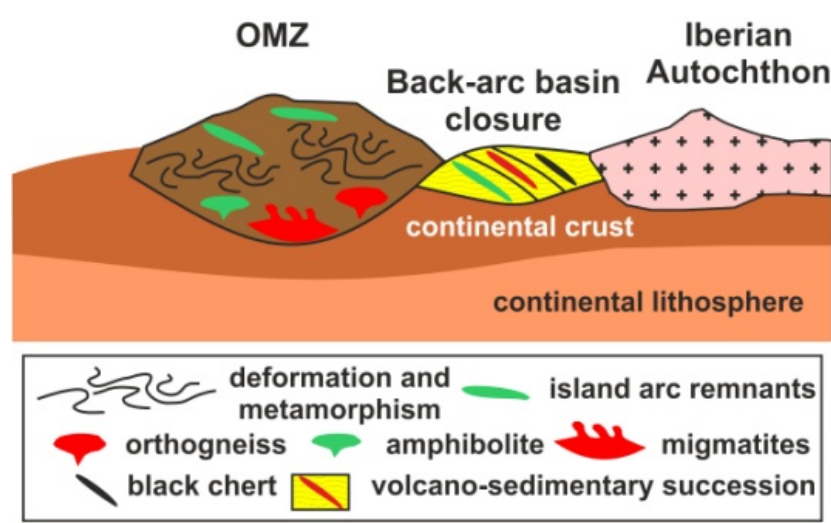

IV) Intrusion of depleted mantle magmas at the Tomar-Badajoz-Córboda shear zone (TBCSZ) in the Early Ordovician (ca. 483-477 Ma).

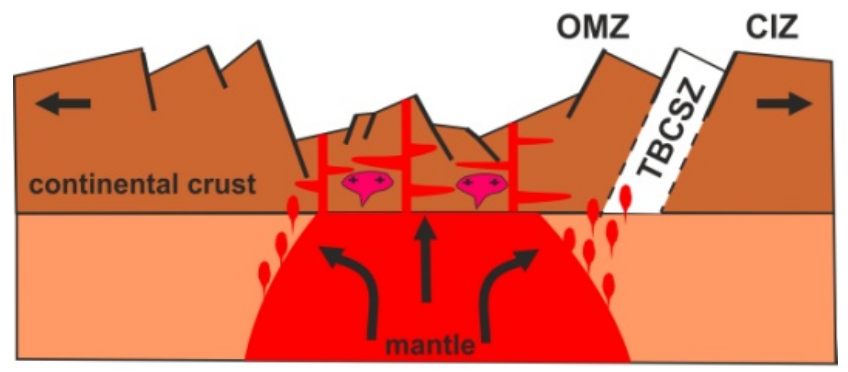

alkaline magmatism $p$ depleted mantle

Fig. 10 
Table 1a $\mathrm{U}$ - Pb isotopic data for zircon, monazite and titanite of the rocks from Sardoal Complex, Central Portugal.

\begin{tabular}{|c|c|c|c|c|c|c|c|c|c|c|c|c|c|c|c|}
\hline \multirow[b]{2}{*}{ Fraction } & \multirow[b]{2}{*}{$\begin{array}{c}\text { Weight } \\
\text { (mg) }\end{array}$} & \multicolumn{2}{|c|}{ Concentration } & \multicolumn{2}{|c|}{ Measured } & \multicolumn{7}{|c|}{ Corrected Atomic Ratios* } & \multicolumn{3}{|c|}{ Age Ma } \\
\hline & & $\begin{array}{c}U \\
(\mathrm{ppm})\end{array}$ & $\begin{array}{l}\mathrm{Pb} \\
\mathrm{rad} \\
(\mathrm{ppm})\end{array}$ & $\begin{array}{c}\text { Total } \\
\text { common } \\
\mathrm{Pb}(\mathrm{pg})\end{array}$ & $\begin{array}{l}{ }^{206} \mathrm{~Pb} \\
{ }^{204} \mathrm{~Pb}\end{array}$ & \begin{tabular}{c}
${ }^{208} \mathrm{~Pb}$ \\
\hdashline${ }^{206} \mathrm{~Pb}$
\end{tabular} & ${ }^{206} \mathrm{~Pb}$ & $2 \sigma$ & \begin{tabular}{c}
${ }^{207} \mathrm{~Pb}$ \\
\hdashline${ }^{235} \mathrm{U}$
\end{tabular} & $2 \sigma$ & \begin{tabular}{c}
${ }^{207} \mathrm{~Pb}$ \\
\hdashline${ }^{206} \mathrm{~Pb}$ \\
\end{tabular} & $2 \sigma$ & $\begin{array}{c}{ }^{206} \mathrm{~Pb} \\
{ }^{238} \mathrm{U}\end{array}$ & ${ }^{{ }^{207} \mathrm{~Pb}}$ & $\begin{array}{c}{ }^{207} \mathrm{~Pb} \\
{ }^{206} \mathrm{~Pb}\end{array}$ \\
\hline \multicolumn{16}{|c|}{$\begin{array}{l}\text { Quartzo-feldspathic schist (321-140) }\left(39^{\circ} 34^{\prime} 28.66^{\prime \prime} \mathrm{N}, 8^{\circ} 16^{\prime} 2.44^{\prime \prime W}\right) \\
\end{array}$} \\
\hline Z1 2 Irg clr euh prm & 0.002 & 756 & 75.0 & 5.5 & 1748 & 0.0860 & 0.10058 & 66 & 0.8457 & 50 & 0.06098 & 32 & 618 & 622 & 638 \\
\hline Z2 1 Irg clr euh prm & 0.001 & 936 & 87.0 & 5.8 & 972 & 0.0778 & 0.09509 & 56 & 0.7839 & 52 & 0.05979 & 26 & 586 & 588 & 596 \\
\hline Z3 $1 \mathrm{lrg}$ clr euh prm & 0.001 & 1061 & 92.5 & 4.7 & 1285 & 0.0666 & 0.09008 & 42 & 0.7316 & 32 & 0.05890 & 18 & 556 & 557 & 563 \\
\hline Z4 2 Irg clr euh prm & 0.002 & 615 & 98.6 & 4.7 & 2530 & 0.0953 & 0.15452 & 72 & 2.3724 & 114 & 0.11135 & 16 & 926 & 1234 & 1822 \\
\hline Z5 1 euh prm & 0.002 & 172 & 38.5 & 1.3 & 3607 & 0.0803 & 0.21161 & 82 & 4.4025 & 170 & 0.15089 & 34 & 1237 & 1713 & 2356 \\
\hline Z6 1 euh prm & 0.002 & 422 & 38.2 & 4.2 & 1179 & 0.0739 & 0.09293 & 96 & 0.7561 & 84 & 0.05901 & 50 & 573 & 572 & 568 \\
\hline Z7 2 euh prm & 0.004 & 63 & 6.0 & 1.8 & 855 & 0.0947 & 0.09591 & 80 & 0.7849 & 82 & 0.05935 & 60 & 590 & 588 & 580 \\
\hline Z8 1 clr euh prm & 0.001 & 781 & 75.7 & 7.4 & 667 & 0.0832 & 0.09868 & 70 & 0.8157 & 86 & 0.05995 & 54 & 607 & 606 & 602 \\
\hline M1 1 flat euh med yel A & 0.001 & 30735 & 6632.2 & 677 & 269 & 1.7763 & 0.08808 & 88 & 0.7020 & 88 & 0.05780 & 42 & 544 & 540 & 522 \\
\hline M2 1 flat euh med yel A & 0.001 & 20781 & 3859.2 & 247 & 478 & 1.4103 & 0.08708 & 52 & 0.6973 & 44 & 0.05808 & 12 & 538 & 537 & 533 \\
\hline M3 1 Irg flat euh yel A & 0.002 & 25074 & 3838.0 & 523 & 398 & 1.0418 & 0.08444 & 68 & 0.6735 & 58 & 0.05785 & 20 & 523 & 523 & 524 \\
\hline \multicolumn{16}{|c|}{ Carvalhal orthogneiss (gn) $\left(39^{\circ} 28^{\prime} 17.32^{\prime \prime} \mathrm{N}, 8^{\circ} 3^{\prime} 19.34^{\prime \prime W}\right)$} \\
\hline Z1 2 Irg clr euh A & 0.004 & 244 & 37.5 & 1 & 9059 & 366 & 14588 & 78 & & 96 & 0.08577 & 30 & 878 & 1018 & 1333 \\
\hline $\mathrm{Z2} 3 \mathrm{Irg}$ & 0.006 & 255 & 34.7 & 1 & 8544 & 0.1358 & 0.12954 & 64 & 1.4810 & 70 & 0.08292 & 20 & 785 & 923 & 1267 \\
\hline reuh A & 0.008 & 250 & 30.3 & 75 & 209 & 0.1545 & 0.11486 & 62 & 1.1424 & 102 & 0.07214 & 48 & 701 & 774 & 990 \\
\hline Z4 2 It & 0.004 & 220 & 42.8 & 3 & 3767 & 0.1392 & 0.18302 & 96 & 2.4612 & 132 & 0.09753 & 22 & 1083 & 1261 & 1577 \\
\hline Z5 3 & 0.006 & 364 & 102.2 & 7 & 5123 & 0.0961 & 0.25364 & 262 & 6.6954 & 682 & 0.19145 & 40 & 1457 & 2072 & 2755 \\
\hline Z6 11 & 0.002 & 338 & 33.4 & 1 & 3072 & 0.1859 & 0.09204 & 78 & 0.7545 & 90 & 0.05945 & 68 & 568 & 571 & 584 \\
\hline euh $A$ & 0.002 & 360 & 36.6 & 7 & 695 & 0.1415 & 0.09825 & 76 & 0.8222 & 70 & 0.06069 & 46 & 604 & 609 & 628 \\
\hline Z8 1 Irg clr euh A & 0.002 & 244 & 28.2 & 1 & 3545 & 0.2626 & 0.10172 & 64 & 0.8570 & 46 & 0.06110 & 32 & 625 & 628 & 643 \\
\hline Z10 1 clr prm A & 0.002 & 98 & 9.2 & 4 & 288 & 0.1201 & 0.09247 & 108 & 0.7585 & 242 & 0.05949 & 176 & 570 & 573 & 585 \\
\hline $\mathrm{Z} 111 \mathrm{cl}$ & 0.002 & 100 & 56.3 & 3 & 2214 & 0.1109 & 0.49941 & 866 & 13.5602 & 1728 & 0.19693 & 244 & 2611 & 2719 & 2801 \\
\hline $\mathrm{Z} 121 \mathrm{n}$ & 0.002 & 114 & 12.5 & 3 & 486 & 0.3097 & 0.09253 & 124 & 0.7536 & 186 & 0.05907 & 130 & 570 & 570 & 570 \\
\hline Z13 1 & 0.002 & 184 & 18.2 & 4 & 523 & 0.1536 & 0.09502 & 110 & 0.7848 & 172 & 0.05990 & 122 & 585 & 588 & 600 \\
\hline Z14 1 & 0.002 & 132 & 14.6 & 3 & 52 & 0.2894 & 0.09496 & 48 & 0.7817 & 110 & 0.05970 & 76 & 585 & 586 & 593 \\
\hline M1 2 & 0.004 & 2298 & 460.9 & 7 & 7329 & 1.6795 & 0.08475 & 134 & 84 & 110 & 0.05805 & 50 & 524 & 526 & 532 \\
\hline M2 1 & 0.002 & 6156 & 942.8 & 20 & 3346 & 0.9690 & 0.08751 & 76 & 28 & 64 & 0.05825 & 34 & 541 & 540 & 539 \\
\hline M3 2 & 0.004 & 4972 & 864.1 & 6 & 17722 & 1.2802 & 0.08604 & 60 & 382 & 44 & 0.05801 & 26 & 532 & 532 & 530 \\
\hline M4 1 subhed $A$ & 0.002 & 1749 & 696.9 & 88 & 200 & 5.2657 & 0.07279 & 62 & 0.5627 & 112 & 0.05606 & 100 & 453 & 453 & 455 \\
\hline \multicolumn{16}{|c|}{ Sardoal orthogneiss $(10) \quad\left(39^{\circ} 28^{\prime} 18.66^{\prime \prime} \mathrm{N}, 8^{\circ} 3^{\prime} 56.42^{\prime \prime} \mathrm{W}\right.$} \\
\hline Z1 5 clr prms A & 0.007 & 260 & 23.0 & 16 & 678 & 973 & 0.08876 & 100 & & 130 & 055 & 88 & 548 & 563 & 623 \\
\hline $\mathrm{Z2} 5 \mathrm{c}$ & 0.007 & 339 & 28.5 & 2 & 6680 & 0.0859 & 0.08545 & 118 & 0.6878 & 92 & 0.05838 & 44 & 529 & 531 & 544 \\
\hline Z3 2 3:1 & 0.004 & 157 & 14.2 & 2 & 1654 & 0.0914 & 0.09170 & 66 & 0.7535 & 100 & 0.05960 & 76 & 566 & 570 & 589 \\
\hline Z4 $1 \mathrm{c}$ & 0.002 & 440 & 35.7 & 1 & 5666 & 0.0568 & 0.08462 & 40 & 0.6824 & 34 & 0.05849 & 14 & 524 & 528 & 548 \\
\hline $\mathrm{Z5}$ & 0.006 & 128 & 12.8 & 2 & 2327 & 0.0950 & 0.09994 & 76 & 0.8653 & 70 & 0.06280 & 32 & 614 & 633 & 701 \\
\hline Z6 & 0.002 & 272 & 21.7 & 1 & 2103 & 0.0552 & 0.08337 & 58 & 722 & 58 & 0.05848 & 32 & 516 & 522 & 548 \\
\hline Z7 2 clr sharp prm A & 0.004 & 314 & 24.8 & 2 & 3298 & 0.0336 & 0.08407 & 80 & 0.6780 & 70 & 0.05850 & 46 & 520 & 526 & 548 \\
\hline \multicolumn{16}{|c|}{ Souto orthogneiss (311-56) $\left(39^{\circ} 36^{\prime} 31.87^{\prime \prime} N, 8^{\circ} 17^{\prime} 28.01^{\prime \prime W}\right)-$} \\
\hline Z1 1 med clr prm E & 0.001 & 1430 & 265.3 & 4 & 3913 & 782 & 0.18327 & 82 & 36 & 112 & 907 & 22 & 1085 & 1273 & 1607 \\
\hline $\mathrm{Z2} 2 \mathrm{me}$ & 0.002 & 1461 & 162.3 & 4 & 5204 & 0.0589 & 0.11347 & 136 & 1.2537 & 138 & 0.08013 & 42 & 693 & 825 & 1200 \\
\hline Z3 1 med-Irg & 0.001 & 1319 & 123.7 & 5 & 1494 & 0.0741 & 0.09612 & 40 & 0.7949 & 34 & 0.05998 & 14 & 592 & 594 & 603 \\
\hline M1 $1 \mathrm{lrg}$ & 0.002 & 66231 & 12831.3 & 22 & 24826 & 1.5303 & 0.08662 & 42 & 0.6932 & 34 & 0.05804 & 4 & 536 & 535 & 531 \\
\hline M2 1 Irg yel clr sub A & 0.002 & 44622 & 10970.3 & 33 & 11227 & 2.1972 & 0.08733 & 42 & 0.6998 & 34 & 0.05812 & 6 & 540 & 539 & 534 \\
\hline \multicolumn{16}{|c|}{ Olalhas orthogneiss $(311-30) \quad\left(39^{\circ} 38^{\prime} 19.76^{\prime \prime} \mathrm{N}, 8^{\circ} 16^{\prime} 32.65^{\prime \prime W}\right)$} \\
\hline Z1 4 med 3:1 prm E & 0.006 & 443 & 58.0 & 7 & & 575 & 2048 & 54 & & 72 & 396 & 26 & 733 & 1019 & 1696 \\
\hline $\mathrm{Z2} 3 \mathrm{~m}$ & 0.004 & 257 & 27.9 & 7 & 1081 & 0.0859 & 0.10999 & 38 & 0.9757 & 60 & 0.06434 & 30 & 673 & 691 & 753 \\
\hline Z3 5 med 3: & 0.007 & 243 & 23.7 & 10 & 1158 & 0.1223 & 0.09602 & 38 & 0.8003 & 54 & 0.06045 & 32 & 591 & 597 & 620 \\
\hline Z4 3 med prm E & 0.004 & 365 & 41.1 & 11 & 1011 & 0.1359 & 0.10920 & 60 & 0.9555 & 72 & 0.06347 & 34 & 668 & 681 & 724 \\
\hline \multicolumn{16}{|c|}{ Cabeco da Moura amphibolite $(311-1) \quad\left(39^{\circ} 37^{\prime} 57.06^{\prime \prime N}, 8^{\circ} 15^{\prime} 29.24^{\prime \prime W}\right)$} \\
\hline Z1 $15 \mathrm{sml}$ mfacet A & 0.023 & 162 & 13.8 & 2 & 8319 & 0.0763 & 0.08738 & 84 & 38 & 68 & 0.05842 & 36 & 540 & 541 & 546 \\
\hline Z2 $5 \mathrm{sm}$ & 0.007 & 214 & 18.3 & 1 & 5938 & 0.0829 & 0.08681 & 124 & 0.6990 & 100 & 0.05840 & 64 & 537 & 538 & 545 \\
\hline Z3 1 lor & 0.002 & 39 & 3.4 & 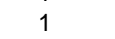 & & 0.0768 & 0.08714 & 104 & 0.7135 & 100 & 0.05938 & 54 & 539 & 547 & 581 \\
\hline Z4 $5 \mathrm{sml}$ rnd A & 0.010 & 59 & 5.0 & 25 & 145 & 0.0693 & 0.08721 & 150 & 0.7088 & 302 & 0.05895 & 240 & 539 & 544 & 565 \\
\hline Vila Nova amphibolite & $\left(39^{\circ} 36^{\prime}\right.$ & $.32 " \mathrm{~N}$ & '16'44 & 4.24"W & & & & & & & & & & & \\
\hline T1 1 med Ip cast $A$ & 0.002 & 1833 & 209.7 & 18 & 1105 & 0.4918 & 0.08563 & 122 & 0.6870 & 90 & 0.05819 & 44 & 530 & 531 & 537 \\
\hline T2 2 med lp cast $A$ & 0.004 & 898 & 101.8 & 21 & 948 & 0.4800 & 0.08550 & 148 & 0.6871 & 112 & 0.05829 & 50 & 529 & 531 & 541 \\
\hline
\end{tabular}

Notes: Z=zircon, M-monazite,T=titanite, 1,2=number of grains, Irg=large, clr=clear, yel=yellow, med=medium,sml=small, prm=prism, $A=a b r a d e d, ~ E=e t c h e d ;$ euh=euhedral; subhed=subhedral; mfacet=multi-faceted. Weights were estimated. Zircon grains were physically abraded (cf. Krogh, 1982), or annealed and etched in HF acid (cf. Mattinson, 2005). * Atomic ratios corrected for fractionation, spike, laboratory blank of 1-4 picograms of common lead, and initial common lead at the age of the sample calculated from the model of Stacey and Kramers (1975), and 0.5-1 picogram U blank. Datum: D_ETRS_1989. 
Table 1b U- $\mathrm{Pb}$ isotopic data for zircon and monazite of the rocks from the Mouriscas Complex, Central Portugal.

\begin{tabular}{|c|c|c|c|c|c|c|c|c|c|c|c|c|c|c|c|}
\hline \multirow[b]{2}{*}{ Fraction } & \multirow[b]{2}{*}{$\begin{array}{l}\text { Weight } \\
\text { (mg) }\end{array}$} & \multicolumn{2}{|c|}{ Concentration } & \multicolumn{2}{|c|}{ Measured } & \multicolumn{7}{|c|}{ Corrected Atomic Ratios* } & \multicolumn{3}{|c|}{ Age Ma } \\
\hline & & $\begin{array}{c}U \\
(\mathrm{ppm})\end{array}$ & $\begin{array}{l}\mathrm{Pb} \\
\mathrm{rad} \\
(\mathrm{ppm})\end{array}$ & $\begin{array}{c}\text { Total } \\
\text { common } \\
\mathrm{Pb}(\mathrm{pg})\end{array}$ & $\begin{array}{l}{ }^{206} \mathrm{~Pb} \\
-{ }^{204} \mathrm{~Pb} \\
\end{array}$ & $\begin{array}{c}{ }^{208} \mathrm{~Pb} \\
-{ }^{206} \mathrm{~Pb} \\
\end{array}$ & $\begin{array}{c}{ }^{206} \mathrm{~Pb} \\
{ }^{238} \mathrm{U} \\
\end{array}$ & $2 \sigma$ & $\begin{array}{l}{ }^{207} \mathrm{~Pb} \\
{ }^{235} \mathrm{U} \\
\end{array}$ & $2 \sigma$ & \begin{tabular}{c}
${ }^{207} \mathrm{~Pb}$ \\
\hdashline${ }^{206} \mathrm{~Pb}$ \\
\end{tabular} & $2 \sigma$ & \begin{tabular}{c}
${ }^{206} \mathrm{~Pb}$ \\
\hdashline${ }^{238} \mathrm{U}$ \\
\end{tabular} & $\begin{array}{c}{ }^{207} \mathrm{~Pb} \\
-{ }^{235} \mathrm{U} \\
\end{array}$ & $\begin{array}{l}{ }^{207} \mathrm{~Pb} \\
{ }^{206} \mathrm{~Pb} \\
\end{array}$ \\
\hline \multicolumn{16}{|c|}{ Amphibolite (321-138) $\left(39^{\circ} 34^{\prime} 35.15^{\prime \prime} \mathrm{N}, 8^{\circ} 15^{\prime} 46.02^{\prime \prime} \mathrm{W}\right)$} \\
\hline Z1 3 med prm E & 0.006 & 772 & 69.3 & 10 & 2494 & 0.1284 & 0.08791 & 56 & 0.7088 & 44 & 0.05848 & 14 & 543 & 544 & 548 \\
\hline Z2 6 med prm E & 0.012 & 1543 & 140.4 & 12 & 8651 & 0.1392 & 0.08834 & 56 & 0.7106 & 46 & 0.05834 & 8 & 546 & 545 & 543 \\
\hline Z3 3 med prm E & 0.006 & 814 & 73.8 & 12 & 2223 & 0.1400 & 0.08802 & 46 & 0.7090 & 36 & 0.05842 & 14 & 544 & 544 & 546 \\
\hline \multicolumn{16}{|c|}{ Amphibolite (58A) $\left(39^{\circ} 28^{\prime} 6.42^{\prime \prime} \mathrm{N}, 8^{\circ} 4^{\prime} 26.41^{\prime \prime W}\right)$} \\
\hline Z1 2 Irg euh prm E & 0.003 & 2141 & 187.7 & 7 & 5166 & 0.1086 & 0.08736 & 62 & 0.7033 & 50 & 0.05840 & 16 & 540 & 541 & 545 \\
\hline $\mathrm{Z2} 3 \mathrm{p}$ & 0.004 & 1723 & 146.7 & 7 & 4662 & 0.0714 & 0.08763 & 40 & 0.7053 & 30 & 0.05837 & 12 & 542 & 542 & 544 \\
\hline Z3 $3 \mathrm{sml}$ euh prm E & 0.003 & 1563 & 137.6 & 5 & 4939 & 0.1090 & 0.08770 & 32 & 0.7061 & 26 & 0.05839 & 10 & 542 & 542 & 545 \\
\hline \multicolumn{16}{|c|}{ Amphibolite (321-M) $\left(39^{\circ} 29^{\prime} 46.96^{\prime \prime N}, 8^{\circ} 9^{\prime} 8.59^{\prime \prime} \mathrm{W}\right)$} \\
\hline Z12 Irg clr euh prm E & 0.005 & 2142 & 186.7 & 4 & 13257 & 0965 & 0.08778 & 58 & 0.7066 & 48 & 0.05838 & 8 & 542 & 543 & 544 \\
\hline Z2 2 Irg clr euh prm E & 0.004 & 2923 & 246.4 & 17 & 3713 & 0.0823 & 0.08595 & 74 & 0.6916 & 58 & 0.05836 & 10 & 532 & 534 & 543 \\
\hline \multicolumn{16}{|c|}{ Protomylonite throndhjemite (165) $\left(39^{\circ} 28^{\prime} 17.17^{\prime \prime N}, 8^{\circ} 5^{\prime} 31.09^{\prime \prime W}\right)$} \\
\hline Z1 2 clr 2:1 prm A & 0.003 & 75 & 6.0 & 1 & 804 & 0.0918 & 0.08100 & 176 & 0.6722 & 142 & 0.06019 & 114 & 502 & 522 & 610 \\
\hline Z2 2 clr 2:1 prm E & 0.002 & 272 & 22.1 & 4 & 732 & 0.0755 & 0.08331 & 42 & 0.6669 & 58 & 0.05806 & 42 & 516 & 519 & 532 \\
\hline Z3 2 clr prm E & 0.002 & 364 & 27.4 & 4 & 894 & 0.0706 & 0.07775 & 20 & 0.6088 & 42 & 0.05679 & 34 & 483 & 483 & 483 \\
\hline Z4 1 clr euh prm E & 0.001 & 253 & 22.1 & 4 & 358 & 0.0697 & 0.08983 & 66 & 0.7224 & 164 & 0.05832 & 120 & 555 & 552 & 542 \\
\hline v sml euh & 0.010 & 36 & 6.9 & 5 & 337 & 2.0608 & 0.07199 & 72 & 0.5691 & 104 & 0.05733 & 98 & 448 & 457 & 504 \\
\hline M2 & 0.004 & 94 & 17.3 & 3 & 650 & 1.9503 & 0.07047 & 100 & 0.5511 & 130 & 0.05672 & 124 & 439 & 446 & 481 \\
\hline M3 4 v sml euh-sbhed & 0.002 & 185 & 46.5 & 2 & 1212 & 2.7845 & 0.07556 & 48 & 0.5903 & 84 & 0.05666 & 74 & 470 & 471 & 478 \\
\hline \multicolumn{16}{|c|}{ Garnet amphibolite (20A) $\left(39^{\circ} 27^{\prime} 56.80^{\prime \prime} \mathrm{N}, 8^{\circ} 4^{\prime} 48.24^{\prime \prime W}\right)$} \\
\hline Z1 4 lrg clr prm A & 0.008 & 54 & 5.1 & 2 & 1273 & 0.3811 & 0.07673 & 54 & 0.6047 & 46 & 0.05716 & 24 & 477 & 480 & 498 \\
\hline Z2 2 Irg clr prm A & 0.004 & 104 & 9.6 & 3 & 719 & 0.3412 & 0.07635 & 58 & 0.5980 & 72 & 0.05680 & 54 & 474 & 476 & 484 \\
\hline Z3 2 Irg clr prm/frg A & 0.004 & 99 & 7.7 & 3 & 727 & 0.1562 & 0.07455 & 52 & 0.5836 & 56 & 0.05678 & 46 & 464 & 467 & 483 \\
\hline Z4 2 clr prm E & 0.002 & 63 & 5.6 & 4 & 174 & 0.2865 & 0.07683 & 72 & 0.6012 & 234 & 0.05675 & 208 & 477 & 478 & 482 \\
\hline Z5 4 clr prm E & 0.004 & 154 & 13.8 & 4 & 689 & 0.3028 & 0.07663 & 38 & 0.5995 & 48 & 0.05674 & 38 & 476 & 477 & 482 \\
\hline Z6 2 clr prm E & 0.002 & 329 & 30.1 & 5 & 653 & 0.3220 & 0.07691 & 62 & 0.6022 & 80 & 0.05679 & 72 & 478 & 479 & 483 \\
\hline Z72 clr prm E & 0.002 & 99 & 8.6 & 5 & 215 & 0.2625 & 0.07674 & 132 & 0.6016 & 168 & 0.05686 & 148 & 477 & 478 & 486 \\
\hline
\end{tabular}

Notes: Z=zircon, M-monazite,T=titanite, 1,2=number of grains, Irg=large, clr=clear, yel=yellow, med=medium,sml=small, prm=prism, A=abraded, E=etched; euh=euhedral; subhed=subhedral; mfacet=multi-faceted. Weights were estimated. Zircon grains were physically abraded (cf. Krogh, 1982), or annealed and etched in HF acid (cf. Mattinson, 2005). * Atomic ratios corrected for fractionation, spike, laboratory blank of 1-4 picograms of common lead, and initial common lead at the age of the sample calculated from the model of Stacey and Kramers (1975), and 0.5-1 picogram U blank. Datum: D_ETRS_1989. 
Table 2a Rb-Sr isotopic data of the rocks from Sardoal Complex and Mouriscas Complex, Central Portugal.

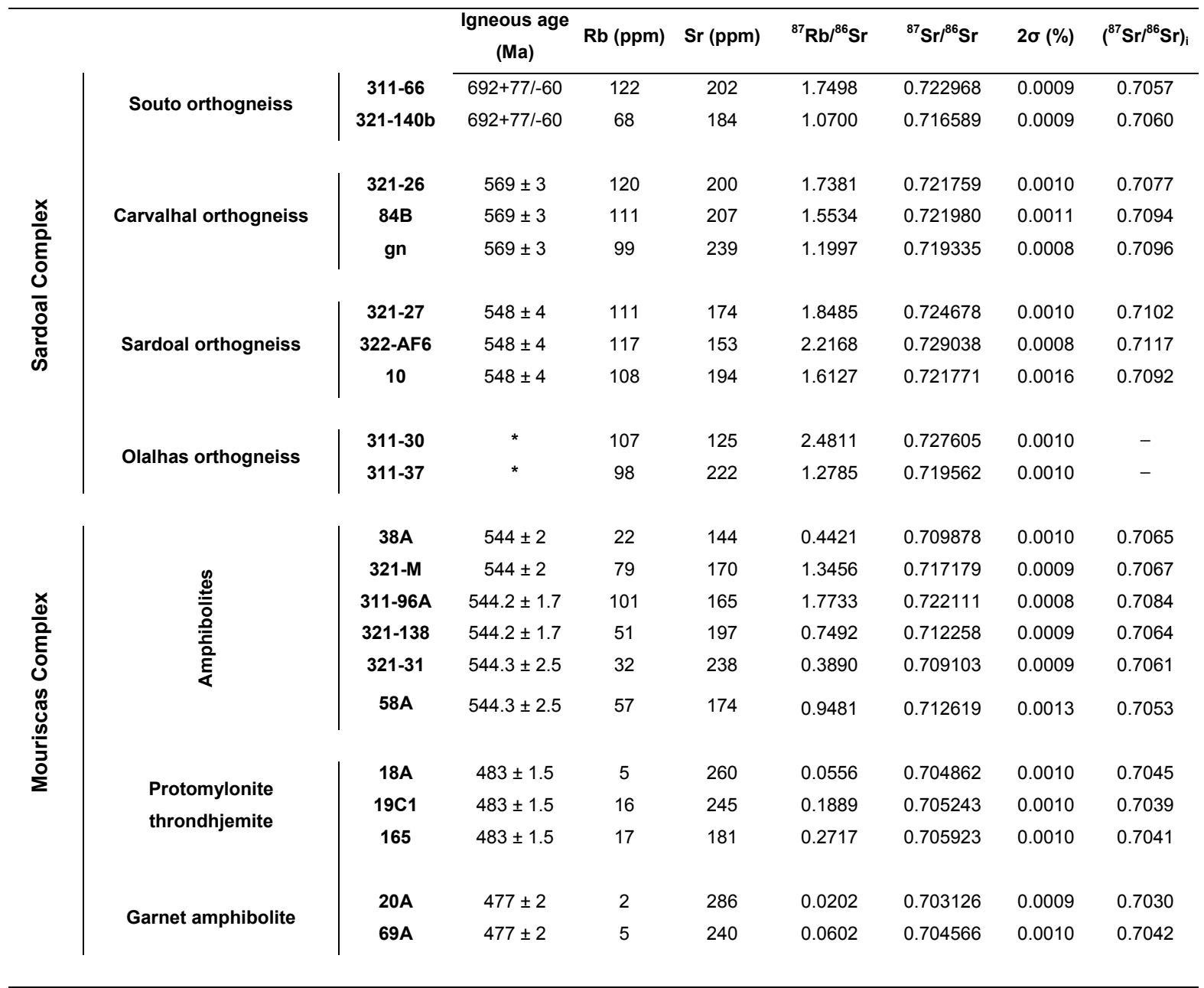

\footnotetext{
* Unknown igneous age; - not determined.
} 
Table 2b Sm-Nd isotopic data of rocks from Sardoal Complex and Mouriscas Complex, Central Portugal.

\begin{tabular}{|c|c|c|c|c|c|c|c|c|c|c|c|}
\hline & & & $\begin{array}{c}\text { Igneous age } \\
\text { (Ma) }\end{array}$ & $\begin{array}{c}\mathrm{Sm} \\
(\mathrm{ppm})\end{array}$ & $\begin{array}{c}\mathrm{Nd} \\
(\mathrm{ppm})\end{array}$ & ${ }^{147} \mathrm{Sm} /{ }^{144} \mathrm{Nd}$ & ${ }^{143} \mathrm{Nd} /{ }^{144} \mathrm{Nd}$ & $2 \sigma(\%)$ & $\left(\left(^{143} \mathrm{Nd} /{ }^{144} \mathrm{Nd}\right)_{\mathrm{i}}\right.$ & $\varepsilon \mathrm{Nd}_{\mathrm{t}}$ & $\begin{array}{l}T_{D M} \\
\text { (Ga) }\end{array}$ \\
\hline \multirow{10}{*}{ 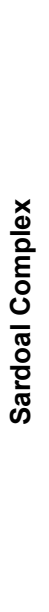 } & \multirow{3}{*}{ Souto orthogneiss } & $311-66$ & $692+77 /-60$ & 7.41 & 36.6 & 0.1153 & 0.511979 & 0.0007 & 0.511573 & -7.3 & 1.65 \\
\hline & & $321-140 b$ & $692+77 /-60$ & 5.07 & 23.9 & 0.1265 & 0.512123 & 0.0007 & 0.511677 & -5.2 & 1.60 \\
\hline & & $321-26$ & $569 \pm 3$ & 5.34 & 28.8 & 0.1124 & 0.512027 & 0.0007 & 0.511623 & -6.0 & 1.53 \\
\hline & \multirow[t]{2}{*}{ Carvalhal orthogneiss } & 84B & $569 \pm 3$ & 6.15 & 32.4 & 0.1126 & 0.511947 & 0.0007 & 0.511543 & -7.6 & 1.65 \\
\hline & & gn & $569 \pm 3$ & 4.35 & 24.1 & 0.1114 & 0.511907 & 0.0007 & 0.511492 & -8.1 & 1.69 \\
\hline & \multirow{3}{*}{ Sardoal orthogneiss } & $321-27$ & $548 \pm 4$ & 5.16 & 26.6 & 0.1146 & 0.512029 & 0.0007 & 0.511602 & -5.9 & 1.56 \\
\hline & & 322-AF6 & $548 \pm 4$ & 4.33 & 24.7 & 0.1184 & 0.512017 & 0.0007 & 0.511576 & -6.4 & 1.64 \\
\hline & & 10 & $548 \pm 4$ & 6.39 & 28.1 & 0.1248 & 0.512078 & 0.0007 & 0.511630 & -5.9 & 1.65 \\
\hline & \multirow{2}{*}{ Olalhas orthogneiss } & $311-30$ & * & 5.76 & 27.6 & 0.1205 & 0.512138 & 0.0007 & - & - & 1.48 \\
\hline & & 311-37 & * & 7.54 & 40 & 0.1136 & 0.512016 & 0.0007 & - & - & 1.56 \\
\hline \multirow{11}{*}{ 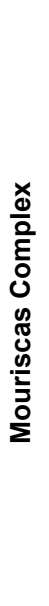 } & \multirow{6}{*}{ 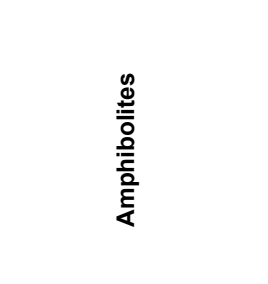 } & $38 \mathrm{~A}$ & $544 \pm 2$ & 1.83 & 7.73 & 0.1486 & 0.512317 & 0.0007 & 0.511787 & -2.9 & 1.69 \\
\hline & & 321-M & $544 \pm 2$ & 2.4 & 9.49 & 0.1516 & 0.512302 & 0.0006 & 0.511762 & -3.4 & 1.81 \\
\hline & & $311-96 A$ & $544.2 \pm 1.7$ & 6.27 & 25.9 & 0.1457 & 0.512270 & 0.0006 & 0.511751 & -3.6 & 1.73 \\
\hline & & $321-138$ & $544.2 \pm 1.7$ & 4.44 & 18.6 & 0.1429 & 0.512294 & 0.0008 & 0.511785 & -3.0 & 1.61 \\
\hline & & $321-31$ & $544.3 \pm 2.5$ & 5 & 21.7 & 0.1318 & 0.512231 & 0.0007 & 0.511761 & -3.4 & 1.51 \\
\hline & & $58 \mathrm{~A}$ & $544.3 \pm 2.5$ & 2.71 & 9.33 & 0.1735 & 0.512720 & 0.0007 & 0.512102 & 3.2 & 1.22 \\
\hline & \multirow{3}{*}{$\begin{array}{l}\text { Protomylonite } \\
\text { throndhjemite }\end{array}$} & $18 \mathrm{~A}$ & $483 \pm 1.5$ & 3.45 & 16.3 & 0.1169 & 0.512646 & 0.0007 & 0.512276 & 5.1 & 0.64 \\
\hline & & $19 \mathrm{C} 1$ & $483 \pm 1.5$ & 2.99 & 15.8 & 0.1017 & 0.512609 & 0.0007 & 0.512287 & 5.3 & 0.61 \\
\hline & & 165 & $483 \pm 1.5$ & 3.83 & 17.8 & 0.1174 & 0.512644 & 0.0007 & 0.512273 & 5.0 & 0.65 \\
\hline & \multirow{2}{*}{ Garnet amphibolite } & $20 \mathrm{~A}$ & $477 \pm 2$ & 4.49 & 17.1 & 0.1572 & 0.512934 & 0.0006 & 0.512443 & 8.2 & 0.34 \\
\hline & & $69 \mathrm{~A}$ & $477 \pm 2$ & 3.82 & 14.2 & 0.1387 & 0.512798 & 0.0007 & 0.512365 & 6.7 & 0.52 \\
\hline
\end{tabular}

* Unknown igneous age; - not determined; The $\varepsilon_{\mathrm{Nd}}$ values are calculated using ${ }^{147} \mathrm{Sm} /{ }^{144} \mathrm{Nd}=0.1967$ and ${ }^{143} \mathrm{Nd} /{ }^{144} \mathrm{Nd}=0.512638$ values for the present day chondrite uniform reservoir (CHUR); $\mathrm{T}_{\mathrm{DM}}$ is calculated with respect to the DePaolo (1981a). 
Appendix 1. Petrographic features of the rocks from Sardoal Complex and Mouriscas Complex, Central Portugal.

\begin{tabular}{|c|c|c|c|c|c|c|}
\hline Unit & \multicolumn{2}{|c|}{ Rock-type } & Texture & Mineral assemblage & $\begin{array}{l}\text { Igneous } \\
\text { age (Ma) }\end{array}$ & $\begin{array}{l}\text { Metamorphic } \\
\text { age (Ma) }\end{array}$ \\
\hline \multirow{7}{*}{ 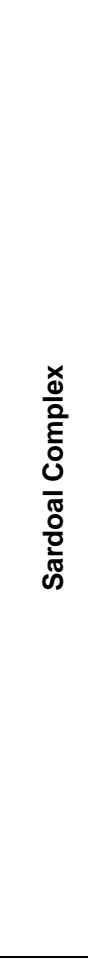 } & \multicolumn{2}{|c|}{ Quartzo-feldspathic schist } & $\begin{array}{l}\text { Fine- to } \\
\text { medium- grained; } \\
\text { porphyroclastic, } \\
\text { mylonitic foliation }\end{array}$ & $\begin{array}{c}\mathrm{Qtz}+\mathrm{Olg}+\mathrm{Bt}+\mathrm{Ms} \pm \mathrm{Kfs} \pm \mathrm{Sil} \pm \mathrm{Alm} \\
\pm \mathrm{Zrn} \pm \mathrm{Tur}+\mathrm{llm} \pm \mathrm{Rt} \pm \mathrm{Mnz} \pm \mathrm{Ap} \pm \mathrm{Ab} \pm \mathrm{Ep}\end{array}$ & $692+77 /-60$ & $538 \pm 2$ \\
\hline & \multirow{4}{*}{ Orthogneiss } & Souto & $\begin{array}{l}\text { Medium- to } \\
\text { coarse-grained; } \\
\text { porphyroclastic, } \\
\text { mylonitic foliation }\end{array}$ & $\begin{array}{c}\mathrm{Qtz}+\mathrm{Olg}+\mathrm{Bt}+\mathrm{Ms} \pm \mathrm{Kfs} \pm \mathrm{Alm} \\
\pm \mathrm{Sil}+\mathrm{Zrn} \pm \mathrm{Tur} \pm \mathrm{Mnz}+\mathrm{Ap}+\mathrm{llm}+\mathrm{Rt}\end{array}$ & - & $539 \pm 2$ \\
\hline & & Carvalhal & $\begin{array}{l}\text { Fine- to } \\
\text { medium-grained; } \\
\text { porphyroclastic, } \\
\text { mylonitic foliation } \\
\end{array}$ & $\begin{array}{l}\mathrm{Qtz}+\mathrm{Olg} \pm \mathrm{Ads}+\mathrm{Or}+\mathrm{Mc}+\mathrm{Bt}+\mathrm{Ms} \pm \mathrm{Tur} \\
\pm \mathrm{Alm}+\mathrm{Zrn}+\mathrm{Ap}+\mathrm{Mnz} \pm \mathrm{llm} \pm \mathrm{Rt} \pm \mathrm{Mag}\end{array}$ & $569 \pm 3$ & $540 \pm 5$ \\
\hline & & Sardoal & $\begin{array}{l}\text { Coarse-grained; } \\
\text { augen texture }\end{array}$ & $\begin{array}{l}\mathrm{Qtz}+\mathrm{Olg}+\mathrm{Or}+\mathrm{Bt}+\mathrm{Ms} \pm \mathrm{Sil} \pm \text { Tur } \\
+\mathrm{Zrn}+\mathrm{Ap} \pm \mathrm{llm} \pm \mathrm{Mag} \pm \mathrm{Rt} \pm \mathrm{Py}\end{array}$ & $548 \pm 4$ & - \\
\hline & & Olalhas & $\begin{array}{l}\text { Fine- to } \\
\text { medium-grained; } \\
\text { porphyroclastic, } \\
\text { mylonitic foliation }\end{array}$ & $\begin{array}{l}\mathrm{Qtz}+\mathrm{Olg}+\mathrm{Bt}+\mathrm{Ms} \pm \mathrm{Kfs} \pm \mathrm{Sil} \pm \mathrm{St} \\
\pm \mathrm{Alm} \pm \mathrm{Tur}+\mathrm{Zrn}+\mathrm{Ap} \pm \mathrm{Ilm} \pm \mathrm{Py}\end{array}$ & - & - \\
\hline & \multirow{2}{*}{ Amphibolite } & Cabeço da Moura & $\begin{array}{l}\text { fine-grained; } \\
\text { granoblastic to } \\
\text { nematoblastic; } \\
\quad \text { foliated }\end{array}$ & $\begin{array}{c}\mathrm{Mg}-\mathrm{Hbl} \pm \mathrm{Fe} 2-\mathrm{Hbl} \pm \mathrm{Fe} 2-\mathrm{Ed}+\mathrm{Lab} \\
\pm \mathrm{Ads} \pm \mathrm{Byt}+\mathrm{Di} \pm \mathrm{Aug}+\mathrm{Ilm}+\mathrm{Zrn} \\
+\mathrm{Ttn}+\mathrm{Ap}+\mathrm{Qtz} \pm \mathrm{Mag} \pm \mathrm{Py} \pm \mathrm{Act} \pm \mathrm{Ep}\end{array}$ & - & $539 \pm 3$ \\
\hline & & Vila Nova & $\begin{array}{l}\text { fine-grained; } \\
\text { granoblastic to } \\
\text { nematoblastic; } \\
\text { foliated }\end{array}$ & $\begin{array}{l}\mathrm{Mg}-\mathrm{Hbl} \pm \mathrm{Prg}+\mathrm{Ads}+\mathrm{Lab}+\mathrm{Di}+\mathrm{Ilm} \\
+\mathrm{Ttn}+\mathrm{Ap}+\mathrm{Qtz} \pm \mathrm{Py} \pm \mathrm{Act} \pm \mathrm{Ep}\end{array}$ & - & $529 \pm 5$ \\
\hline \multirow{5}{*}{ 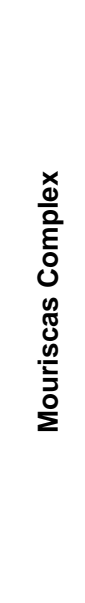 } & \multirow{3}{*}{\multicolumn{2}{|c|}{ Amphibolite }} & $\begin{array}{l}\text { medium-grained; } \\
\text { relic igneous } \\
\text { texture }\end{array}$ & $\begin{aligned} & \mathrm{Ads}+\mathrm{Lab}+\mathrm{Mg}-\mathrm{Hbl}+\mathrm{Fe} 2-\mathrm{Ts} \\
+ & \mathrm{Qtz}+\mathrm{Bt}+\mathrm{Tur}+\mathrm{Zrn}+\mathrm{Ilm}+\mathrm{Ttn}\end{aligned}$ & $544.2 \pm 1.7$ & - \\
\hline & & & $\begin{array}{c}\text { fine-grained; } \\
\text { granofelsic texture }\end{array}$ & $\begin{array}{l}\text { Ads + Lab + Mg-Hbl + Act + Qtz } \\
\quad+C h l+E p+Z r n+A p+I l m\end{array}$ & $544.3 \pm 2.5$ & - \\
\hline & & & $\begin{array}{l}\text { medium-grained; } \\
\text { porphyroclastic, } \\
\text { mylonitic fabric } \\
\end{array}$ & $\begin{array}{l}\text { Ads + Mg-Hbl + Fe2-Ts + Cum } \\
+\mathrm{Qtz}+\mathrm{Bt}+\mathrm{Zrn}+\mathrm{Ap}+\mathrm{Ilm}+\mathrm{Py}\end{array}$ & $544 \pm 2$ & - \\
\hline & \multicolumn{2}{|c|}{ Protomylonite trondhjemite } & $\begin{array}{l}\text { medium- to } \\
\text { coarse-grained; } \\
\text { porphyroclastic, } \\
\text { mylonitic fabric }\end{array}$ & $\begin{array}{c}\mathrm{Qtz}+\mathrm{Olg}+\mathrm{Ms}+\mathrm{Bt}+\mathrm{Sil}+\mathrm{Alm} \\
+\mathrm{St} \pm \mathrm{Or}+\mathrm{Zrn}+\mathrm{Mnz}+\mathrm{Ap} \pm \mathrm{Ilm} \pm \mathrm{Rt}\end{array}$ & $483 \pm 1.5$ & - \\
\hline & \multicolumn{2}{|c|}{ Garnet amphibolite } & $\begin{array}{l}\text { medium- to } \\
\text { coarse-grained; } \\
\text { porhyroblastic, } \\
\text { foliated }\end{array}$ & $\begin{array}{l}\text { Ads } \pm \text { Olg + Gru + Fe2-Ts + Bt + Qtz } \\
+ \text { Alm + Chl + Ep + Zrn + Ilm } \pm \text { Mag }\end{array}$ & $477 \pm 2 \mathrm{Ma}$ & - \\
\hline \multicolumn{7}{|c|}{$\begin{array}{l}\text { Mineral abbreviations from Siivola and Schmid (2007): Ab, Albite; Act, Actinolite; Alm, Almandine; Ap, Apatite; Aug, Augite; Bt, Biotite; Chl } \\
\text { Chlorite; Cum, Cummingtonite; Di, Diopside; Ep, Epidote; Fe2-Ed, Ferro-Edenite; Fe2-Hbl, Ferrohornblende; Fe2-Ts, Ferrotschermakite } \\
\text { Gru, Grunerite; Ilm, Ilmenite; Kfs, K-feldspar; Mag, Magnetite; Mc, Microcline; Mg-Hbl, Magnesiohornblende; Mnz, Monazite; Ms, Muscovite } \\
\text { Or, Orthoclase; Prg, Pargasite; Py, Pyrite; Qtz, Quartz; Rt, Rutile; Sil, Sillimanite; St, Staurolite; Ttn, Titanite; Tur, Tourmaline; Zrn, Zircon } \\
\text { Other mineral abbreviations: Ads, Andesine; Byt, Bytownite; Lab, Labradorite; Olg, Oligoclase. }\end{array}$} \\
\hline
\end{tabular}


Appendix 2. Representative analyses of minerals of Cabeço da Moura amphibolite (sample 311-1), Central Portugal.

\begin{tabular}{|c|c|c|c|c|c|c|c|c|c|}
\hline & Mg-hbl 1 & Mg-hbl 2 & Mg-hbl 3 & & Di (Cpx 1) & Di (Cpx 2) & & Lab (PI) & Byt (PI) \\
\hline $\mathrm{SiO}_{2}$ & 45.10 & 46.24 & 46.42 & $\mathrm{SiO}_{2}$ & 51.79 & 51.43 & $\mathrm{SiO}_{2}$ & 52.45 & 49.65 \\
\hline $\mathrm{TiO}_{2}$ & 1.55 & 1.44 & 1.33 & $\mathrm{TiO}_{2}$ & 0.22 & 0.32 & $\mathrm{TiO}_{2}$ & 0.00 & 0.06 \\
\hline $\mathrm{Al}_{2} \mathrm{O}_{3}$ & 9.58 & 9.32 & 8.94 & $\mathrm{Al}_{2} \mathrm{O}_{3}$ & 1.46 & 1.75 & $\mathrm{Al}_{2} \mathrm{O}_{3}$ & 30.18 & 31.43 \\
\hline $\mathrm{Cr}_{2} \mathrm{O}_{3}$ & 0.18 & 0.09 & 0.04 & $\mathrm{FeO}$ & 9.66 & 10.16 & $\mathrm{FeO}$ & 0.03 & 0.11 \\
\hline $\mathrm{FeO}$ & 15.01 & 14.54 & 14.55 & $\mathrm{Cr}_{2} \mathrm{O}_{3}$ & 0.03 & 0.00 & MnO & 0.01 & 0.08 \\
\hline MnO & 0.27 & 0.27 & 0.21 & MnO & 0.38 & 0.30 & MgO & 0.00 & 0.01 \\
\hline MgO & 11.39 & 11.67 & 12.04 & MgO & 12.67 & 12.47 & $\mathrm{BaO}$ & 0.00 & 0.08 \\
\hline $\mathrm{CaO}$ & 11.53 & 11.74 & 11.81 & $\mathrm{CaO}$ & 23.22 & 22.97 & $\mathrm{CaO}$ & 13.01 & 15.00 \\
\hline $\mathrm{Na}_{2} \mathrm{O}$ & 1.46 & 1.29 & 1.29 & $\mathrm{Na}_{2} \mathrm{O}$ & 0.23 & 0.21 & $\mathrm{Na}_{2} \mathrm{O}$ & 3.77 & 2.87 \\
\hline $\mathrm{K}_{2} \mathrm{O}$ & 0.16 & 0.12 & 0.11 & $\mathrm{~K}_{2} \mathrm{O}$ & 0.00 & 0.02 & $\mathrm{~K}_{2} \mathrm{O}$ & 0.01 & 0.02 \\
\hline \multirow[t]{2}{*}{ Total } & 96.23 & 96.73 & 96.75 & Total & 99.66 & 99.63 & $\mathrm{P}_{2} \mathrm{O}_{5}$ & 0.13 & 0.11 \\
\hline & & & & & & & Total & 99.59 & 99.40 \\
\hline
\end{tabular}

